\title{
Researching at the Intersection of Innovation, Operations Management, and Entrepreneurship
}

\section{INTRODUCTION}

Although innovation is a critical component of entrepreneurship (e.g., innovation is a dimension of firms' entrepreneurial orientation [Covin \& Slevin, 1989]), it seems that the fields of innovation and entrepreneurship run in parallel, with little interaction occurring between the two. While it is unfortunate there has not been more interaction, cross-fertilization, and the co-production of knowledge, the current situation represents a research opportunity - a research opportunity that we begin to explore in this chapter. Innovation refers to the creation of a new product, process, or service that an organization has created for the market; it represents the commercialization of an invention, where invention is an "act of insight” (Li \& Atuahene-Gima, 2001, p. 1124). Innovation has been found to lead to enhanced performance in new ventures (Capon, Farley, \& Hoenig, 1990; Li \& Atuahene-Gima, 2001), superior firm performance (Hull \& Rothenberg, 2008; Thornhill, 2006), and dynamic firm capabilities (Eisenhardt \& Martin, 2000; Teece, Pisano, \& Shuen, 1997). Not surprisingly, innovation scholars have been interested in understanding what makes some firms more innovative than others. Indeed, the innovation literature has produced a long list of antecedents (for a meta-analysis,

The link to operations management in this chapter is largely based on Shepherd and Patzelt (2013).

D.A. Shepherd, H. Patzelt, Trailblazing in Entrepreneurship, DOI 10.1007/978-3-319-48701-4_4 
see Damanpour, 1991) including inter-firm cooperation (Shan, Walker, \& Kogut, 1994), network position (Tsai, 2001), market orientation (Atuahene-Gima, 1996), and industry structure (Teece, 1996). The corporate entrepreneurship literature has also found that innovation outcomes are associated with growth (Burgelman, 1984), higher profitability (Zahra \& Covin, 1995), and competitive advantage (Covin \& Miles, 1999). (We note this latter point to reinforce our earlier point that while innovation and corporate entrepreneurship cover much of the same ground, one makes little reference to the other and vice versa [for an exception, see Morris, Kuratko, \& Covin, 2010].)

To explore the possibilities at the intersection of innovation and entrepreneurship, we focus on two cornerstones of the innovation literature and start to blend them with those in the entrepreneurship literature to advance our understanding of entrepreneurship (and hopefully also begin to make important contributions to the body of knowledge on innovation). Those cornerstones involve absorptive capacity (ACAP) as a source of potential innovations and stage gates as a process of evaluating potential innovations. In this chapter, we also draw on the field of operations to explain how the entrepreneurial process can be managed more effectively. Therefore, we hope that this chapter generates contributions in the following ways.

First, ACAP is central to capturing and using external information to generate innovations (Cohen \& Levinthal, 1990; Zahra \& George, 2002). Although ACAP applies to both the individual and organizational levels of analysis (Cohen \& Levinthal, 1990), innovation scholars have focused almost exclusively at the firm level of analysis. In this chapter, we explore ACAP at the individual level within the entrepreneurial process to generate ideas for future contributions to knowledge. Specifically, we are interested in the role different dimensions of ACAP play in the identification and exploitation of potential opportunities and the ways the identification and exploitation of potential opportunities can influence ACAP.

Second, although innovation outcomes are often classified as incremental or radical (Dewar \& Dutton, 1986; Ettlie, Bridges, \& O'keefe, 1984) and perhaps also architectural (Galunic \& Eisenhardt, 2001; Henderson \& Clark, 1990), with radical innovations representing risky investments, entrepreneurship research focuses on the high uncertainty surrounding potential opportunities (Knight, 1921; McMullen \& Shepherd, 2006). In this chapter, we investigate the stage-gate process for evaluating innovations in terms of potential opportunities characterized by high uncertainty. 
This "bringing together" of an innovation-evaluation process for the purpose of evaluating a potential entrepreneurial opportunity raises a number of critical issues that, if solved, can make important contributions to both the innovation and the entrepreneurship literatures.

Finally, there is a substantial literature on operations management, which has been developed in the context of managing innovation within established firms (Khazanchi, Lewis, \& Boyer, 2007; Sun, Hong, \& $\mathrm{Hu}, 2014$; Tatikonda \& Rosenthal, 2000; Vickery, Jayaram, Droge, \& Calantone, 2003). Thinking about operations management in the context of managing opportunity identification/evaluation within an emerging organization-entrepreneurial operations-provides ample opportunities to contribute to the further development of the operations management, innovation, and entrepreneurship fields.

\section{ACAP and the Entrepreneurial Process}

Central to explanations of innovation and entrepreneurship is the construct of ACAP. ACAP refers to the "ability of a firm to recognize the value of new external information, assimilate it, and apply it to commercial ends" (Cohen \& Levinthal, 1990, p. 127); thus, ACAP facilitates the innovation process (Mueller, 1962; von Hippel, 1988). This firm capability is believed to be a function of the firm's prior and related knowledge (Cohen \& Levinthal, 1990). That is, the firm's knowledge helps the firm learn about and from external knowledge sources to create new knowledge. This internal knowledge (as the source of ACAP) can be created through research and development (Allen, 1977; Cohen \& Levinthal, 1990; Tilton, 1971) and manufacturing operations (Abernathy \& Utterback, 1978; Rosenberg, 1982). Therefore, the notion of ACAP rests on the simple generalization that "prior knowledge permits the assimilation and exploitation of new knowledge" (Cohen \& Levinthal, 1990, pp. 135-136). However, not all prior knowledge is equally useful. It appears that some of the firm's prior knowledge needs to be related to the new knowledge to enable assimilation, whereas other parts of the firm's prior knowledge need to be different from the new knowledge to facilitate creative use of the new knowledge (Cohen \& Levinthal, 1990).

Zahra and George (2002) proposed that ACAP comprises four dimensions that can be categorized into two groups: ACAP is composed of potential absorptive capacity (PACAP) (Group 1), which includes the set of organizational routines and processes by which firms (Dimension 
1) acquire and assimilate (Dimension 2) new knowledge, and realized absorptive capacity (RACAP) (Group 2), which refers to the set of organizational routines and processes by which firms transform (Dimension 3 ) and exploit (Dimension 4) new knowledge. While PACAP "makes the firm receptive to acquiring and assimilating external knowledge," RACAP "reflects the firm's capacity to leverage knowledge that has been absorbed" (Zahra \& George, 2002, p. 190). PACAP provides the basis for adaptation, especially in high-velocity environments, and involves the acquisition and assimilation of new knowledge. Acquisition refers to a firm's ability to identify and obtain external information that is important to its operations (Zahra \& George, 2002). It is believed that the greater the firm's acquisition capability, the more quickly it can gather higher-quality information (Kim, 1997a, 1997b). Assimilation refers to a firm's ability to analyze, interpret, and understand the acquired information (Kim, 1997a, 1997b; Szulanski, 1996; Zahra \& George, 2002). The greater this assimilation capability, the more comprehensible the acquired external information is and, therefore, the more this external information is internalized-that is, made available for "use" within the organization.

RACAP refers to the firm's "capacity to leverage the knowledge that has been absorbed" (Zahra \& George, 2002, p. 190) and involves the transformation and exploitation of external knowledge made available through PACAP. Transformation involves a firm's ability to facilitate the combination (and perhaps recombination) of the firm's prior knowledge with the newly acquired knowledge but may also (or instead) involve interpreting existing knowledge in new ways (Zahra \& George, 2002). Exploitation engages the firm's ability to apply the new knowledge in its operations, thereby creating new competences (Zahra \& George, 2002).

Research on ACAP has generally focused on external sources of knowledge given a stock of internal knowledge. External knowledge sources include acquisitions (Chaudhuri \& Tabrizi, 1999) and other forms of international relationships (Vermeulen \& Barkema, 2001), such as alliances (Lane \& Lubatkin, 1998). However, exposure to external sources of knowledge is necessary but not sufficient for transfer (Matusik, 2000); transfer also requires an understanding of the breadth and depth of this exposure, the new information's relatedness to prior knowledge, and the extent to which the new knowledge is different from current internal knowledge (Cockburn \& Henderson, 1998; Lane \& Lubatkin, 1998; Lofstrom, 2000; Matusik \& Heeley, 2001; Van Wijk, Van den Bosch, \& Volberda, 2001). Indeed, ACAP captures the firm's ability to make the 
most of these external sources of potential new knowledge, and the motivation to do so may result from an internal trigger (e.g., an organizational crisis) or an external trigger (e.g., an environmental jolt) (Bradley, Aldrich, Shepherd, \& Wiklund, 2011).

\section{ACAP and Opportunity Generation and Refinement}

The extant research has focused on the external aspects of ACAP as the source of new information and the focal firm as the recipient. That is, scholarly attention has focused on the uni-directional flow of information, albeit with some firms being better able to capitalize on that flow than others (i.e., those that have higher ACAP). However, there are a number of interesting possibilities when we consider ACAP from an entrepreneurship perspective.

First, from an entrepreneurship viewpoint (in particular, see Shepherd, 2015, and Chap. 2), we investigate the flow of information from outside to inside the firm through the social interactions involved when an entrepreneur tests and refines a potential entrepreneurial opportunity. For example, Domurath and Patzelt (2016) showed that entrepreneurs assess foreign market opportunities based on the nature of their informationproviding network in those markets; however, this effect is contingent on entrepreneurs' perceptions of their venture's ACAP being sufficiently developed to acquire, assimilate, transform, and exploit the information received. However, because the concept of ACAP "can best be developed through an examination of the cognitive structures that underlie learning" (Cohen \& Levinthal, 1990, p. 129), we start with the mind in which the learning is stored (which can be at the firm or the individual level of analysis [Cohen \& Levinthal, 1990, pp. 135-136; Walsh, 1995; Walsh \& Ungson, 1991] highlighted that ACAP “applies at both the individual and organizational levels").

Based on prior knowledge or another source of information (e.g., imagination), the mind can generate a potential opportunity. This potential opportunity represents internally generated knowledge, which is often created by experiencing the world. For example, when engaged in a task, an individual can be fully absorbed and make minor adaptations to small perturbations - absorbed coping (Sandberg \& Tsoukas, 2011; Weick, 1999). However, when the tools the individual has are insufficient for problem solving, the problem stands out as an anomaly requiring deliberate reasoning to generate a solution. A potential solu- 
tion in the form of a new product, service, or process presents a potential opportunity. That is, by engaging in activities, the individual comes across new information; an anomaly reflects the acquisition of new information (of a problem), which then triggers efforts to analyze, interpret, and understand the nature of the anomaly (as it does for scholars) (Shepherd \& Sutcliffe, 2011).

After beginning to understand the anomaly, the individual is able to generate conjectures of a potential opportunity (i.e., potential solutions to the anomaly) (Shepherd, McMullen, \& Ocasio, 2016). The individual forms these conjectures of potential opportunities in his or her mind by combining elements of knowledge as a potential solution; undertaking bisociation, with different perspectives offering new insights; and/or otherwise "tapping into" and challenging existing knowledge. The ability to do this is consistent with "assimilation" and "transformation" and is in line with an entrepreneurial mindset (Grégoire, Barr, \& Shepherd, 2010; McGrath \& MacMillan, 2000) that informs entrepreneurial action (Baker \& Nelson, 2005; Smith \& DeGregorio, 2002). The individual can then test the opportunity conjecture in the world-that is, communicate the potential opportunity to a community of inquiry. Although such action is likely to represent probes into an uncertain future (Brown \& Eisenhardt, 1997; McGrath, 1999), it can be considered an application of the new knowledge (in the form of a potential opportunity) that has been created and internalized (Lyles \& Schwenk, 1992) and therefore represents a form of exploitation (Zahra \& George, 2002).

Of course, the process does not stop there. When the entrepreneur releases the potential opportunity from his or her mind into the world, there is an interaction between the community of inquiry and the potential opportunity. This interaction provides new information that reflects how the potential opportunity can be refined, and/or the community of inquiry acts in a way that changes the nature of the potential opportunity. Either way, the community of inquiry, through its interaction with the potential opportunity, generates new information. To the extent that the entrepreneur (i.e., the mind) is able to absorb this new informationnamely, acquire, assimilate, transform, and exploit it - he or she can make additional refinements to the potential opportunity. Therefore, there is a mutual adjustment between the mind and the world through a potential opportunity (Shepherd, 2015; Chap. 2). The extent of this mutual adjustment is likely to be higher for those who have high ACAP. However, given the iterative process of generating and refining potential opportunities 
(described above), a number of important research questions and opportunities remain.

Dimensions of ACAP and the mutual adjustment process of potential opportunities. Rather than think of ACAP as an aggregation of the four dimensions (or of two groups-PACAP and RACAP), perhaps it is more beneficial to think about the extent of mutual adjustment based on the individual's lowest capability. In other words, if acquisition feeds into assimilation, which feeds into transformation, which feeds into exploitation, and this process is recycled based on engaging a community of inquiry, then it is likely that the process can only proceed as effectively as its lowest capability-it is not the average strength of the links that determines the effectiveness of a chain but the strength of its weakest link. However, perhaps some dimensions are more critical in opportunity refinement than others. For example, after a community of inquiry has been engaged, the ability to acquire information may take on less importance than it did in initial idea generation (perhaps because the source of the information is more apparent), or perhaps transformation, while still important, is not as important when the mind is refining a potential opportunity as opposed to generating one in the first place. How does the importance of the different dimensions of ACAP change throughout the entrepreneurial process, especially as it relates to the mutual adjustment process of opportunity refinement?

Potential opportunity and transforming ACAP. As ACAP enables the entrepreneur to refine the potential opportunity, the potential opportunity itself transforms the mind - that is, the idea refined by a community of inquiry transforms the mind of the idea's generator. This transformation is likely to be reflected in the dimensions of ACAP, such as an enhanced ability to acquire, assimilate, transform, and exploit the new knowledge generated by the community of inquiry. Therefore, not only does ACAP facilitate opportunity refinement (and transformation of the community of inquiry), but it also changes as a result of the process. Capturing how the mind is transformed in terms of its ability to acquire, assimilate, transform and exploit knowledge is a critical issue for innovation and entrepreneurship scholars to address. Again, exploring differences in the dimensions of ACAP adds the potential for scope and depth in understanding how a refined opportunity (by the community of inquiry) transforms its originator's mind.

The dynamism of ACAP as a dynamic capability. To stretch our own minds, we reflected on Zahra and George's (2002) notion that 
ACAP is a dynamic capability - it is a capability that facilitates change in an organization's routines, systems, and processes. However, at least in the mutual adjustment process of developing and refining a potential opportunity, ACAP itself will likely change, making the dynamic capability itself dynamic. It is important to think about the mechanisms of this dynamism. This requires greater theorizing about the form of each capability "housed" in the firm. Specifically, what are the routines of a new information-acquisition capability, assimilation capability, transformation capability, and exploitation capability? Given such an understanding, we are in a position to explore how these capabilities change as part of the mutual adjustment process of potential opportunity refinement. These changes may be reflected in one or many of the capabilities and/or in the routines that connect these capabilities. The entrepreneurial process is a particularly appropriate context to explore these ideas because the potential opportunity is not the sole property of the mind as it changes through social interaction (Shepherd, 2015; see also Chap. 2). While the opportunity, as well as the mind, changes as a result of social interaction, so too does the community of inquiry - it is transformed. This transformation of the community of inquiry (over and above change to the potential opportunity) is also information that, if absorbed, can be useful to the entrepreneurial actor. For example, perhaps two communities arise from one as the potential opportunity changes. Recognizing this transformation of the community of inquiry into two could lead to two different versions of the potential opportunity (different forms of refinement) now representing two potential opportunities - one for each community (e.g., customer target segments). Those with superior ACAP are likely to be in a better position to notice and act upon the new knowledge stemming from the bifurcation of the community and of the opportunity.

From the individual to the firm level of analysis. Maintaining a finer-grained treatment of ACAP — considering each of its four dimensions independently-will likely provide greater scope for understanding how a firm generates and refines an opportunity through its interaction with a community (or communities) of inquiry. When investigating the role of ACAP in the generation and refinement of a potential opportunity in the context of an established firm, we need to ask several questions. How does a firm acquire information that generates an anomaly? How does the firm assimilate new knowledge with existing knowledge to understand the problem and then transform prior knowledge of the problem to generate a potential opportunity that is then exploited through interactions with a 
community of inquiry? To address such questions likely requires an investigation of how ACAP — and thus a series of opportunity-related capabilities - is distributed throughout the firm and coordinated. In other words, how are individuals with the ability to acquire, assimilate, transform, and/ or exploit new knowledge positioned within a firm and organized to offer firm-level ACAP for potential opportunity generation and refinement? Further investigations of organizing ACAP for the generation and refinement of potential opportunities will likely benefit from building on the attention-based view of the firm (see Ocasio, 1997; at the individual level for attention and potential opportunity, see Shepherd et al., 2017).

Potential opportunity as a mechanism for creating firm-level ACAP. As mentioned above, as the mind (including ACAP) is transformed throughout the process of potential opportunity refinement, we are able to focus on the flow of knowledge and therefore changes in ACAP rather than rely on a relatively static perspective of ACAP as an endowment. As with most research on firms' stocks of resources, researchers who take an entrepreneurial perspective are interested in how these stocks are created as an organization emerges. Before the emergence of an organization, the individual (eventual founder), alone or with others, generates and refines a potential opportunity (as described above), and as this process proceeds, additional steps are taken toward organizing the exploitation of this potential opportunity (Katz \& Gartner, 1988; Lichtenstein, Dooley, \& Lumpkin, 2006; Tornikoski \& Newbert, 2007). As the result of-or in conjunction with-organizational emergence, the firm itself develops ACAP that is distinct and separate from that of the founder(s). How does the pursuit and refinement of a potential opportunity through a de novo venture help explain the development of firm-level ACAP? Because the potential opportunity central to new firm creation contributes to firmlevel ACAP, it is likely that a path dependence is created - the potential opportunity generates prior knowledge, which, through ACAP, generates and refines subsequent potential opportunities and so forth. Therefore, the formation of ACAP may be a mechanism by which a new organization's first potential opportunity has an imprinting effect on the identification and exploitation of subsequent potential opportunities.

Summary. In Fig. 4.1, we offer a sketch of ACAP's role in the entrepreneurial process. External information can be a source of new knowledge for the identification of a potential opportunity but more so for those with higher ACAP. This ACAP is a function of prior knowledge and is made up of the ability to acquire, assimilate, transform, and exploit information. 


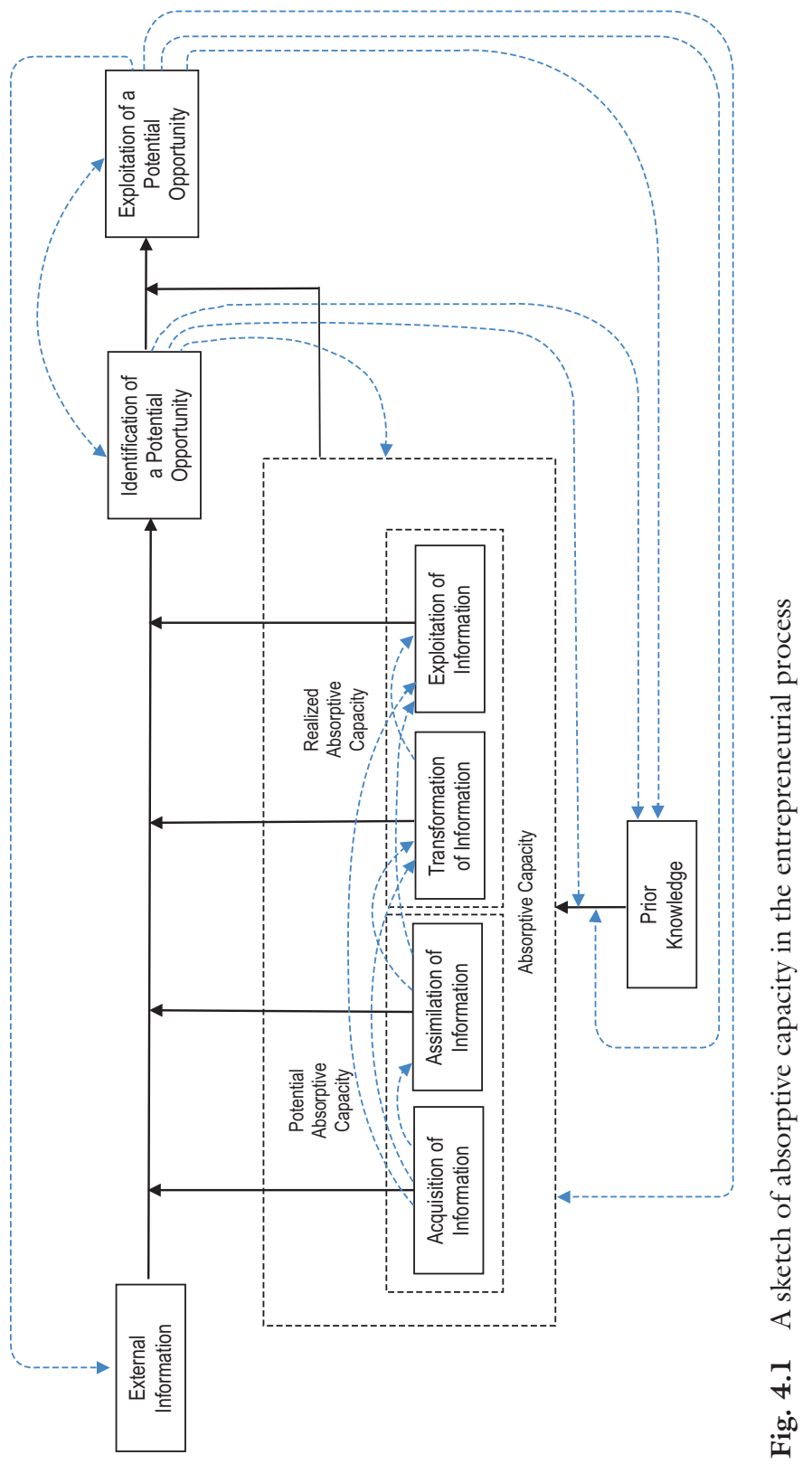


ACAP also facilitates the exploitation of an identified potential opportunity. This exploitation can change the nature of the identified opportunity, the external information, the content of prior knowledge, the relationship prior knowledge has with ACAP, and the level of ACAP. Given the interrelated nature of the dimensions of ACAP, information acquisition likely influences the assimilation, transformation, and exploitation of information; assimilation influences the transformation and exploitation of information; and the transformation of information influences the exploitation of information.

\section{Stages of InNovation ANd Assessing Entrepreneurial Projects}

Critical to innovation is the selection process for investing resourcestime, energy, and money-into entrepreneurial projects (Cooper, 2008, 2013; Cooper, Edgett, \& Kleinschmidt, 2002). This selection process is critical because most organizations have more innovation projects than resources to fund them (Cooper et al., 2002) and because these selection decisions determine the composition of the organization's project portfolio (Behrens \& Patzelt, 2017). In turn, portfolio composition has been found to influence (and reflect) business strategy (Bakker \& Shepherd, 2017; Cooper et al., 2002), product innovation performance (Klingebiel \& Rammer, 2014; van de Vrande, 2013), and-ultimately-firm performance (Salomo, Talke, \& Strecker, 2008; Talke, Salomo, \& Rost, 2010).

The innovation process is typically represented by a number of stages (Urban \& Hauser, 1993; Veryzer, 1998), for example, the stages of (1) idea generation, (2) preliminary assessment, (3) detailed assessment, (4) development, (5) validation, and (6) launch (Cooper \& Kleinschmidt, 1993). In each stage, the project team generates, gathers, and analyzes new information to determine whether the innovation project should proceed to the next stage (Cooper, 2008). With each progressive stage, there is a greater need for resource investment. Each (larger) investment becomes less reversible but generally involves less uncertainty (Bakker \& Shepherd, 2017; Burgelman, 1983; McGrath, 1999).

To add discipline to the innovation process, many organizations use stage gates-decision points between each stage that present the choice to "go" or "kill" the focal entrepreneurial project (e.g., Behrens \& Ernst, 2014). "Go" means the project moves to the next stage of the innovation process, whereas "kill" means the entrepreneurial project is terminated. 
The underlying notion is to kill projects that are weak (i.e., those that provide little evidence of viability) and redeploy its resources to projects that show promise. Staging investments provides a mechanism for containing downside losses (Adner \& Levinthal, 2004; McGrath, 1999). According to the innovation and project management literatures, it is important that these stage gates are pre-defined in terms of "a set of deliverables" that includes things that must be done and achieved, a list of criteria specifying how the project will be assessed (and how the go/kill decision will be made) for each stage, and outputs in terms of the path by which the innovation should progress (Cooper \& Kleinschmidt, 1993). Critical to the stage-gate process is that the gates and their criteria are pre-specified (Boulding, Morgan, \& Staelin, 1997; Cooper \& Kleinschmidt, 1993; Hart \& Milstein, 2003; Schmidt, Sarangee, \& Montoya, 2009). This formal planning of the innovation process (Schultz, Salomo, Brentani, \& Kleinschmidt, 2013) provides structure and sequence (Tatikonda \& Montoya-Weiss, 2001), stabilizes the resource-allocation process (Benner \& Tushman, 2003; Christensen \& Bower, 1996), provides clarity to those working on different aspects of the project (Tatikonda \& Montoya-Weiss, 2001), and reduces - or otherwise manages—risk (Schmidt et al., 2009).

However, one can question whether these entrepreneurial projects involve entrepreneurial risk (as assumed in the go/kill stage-gate process) or uncertainty. Entrepreneurial risk refers to "investments of resources (including the entrepreneur's time and energy) in which the decision maker knows the probability distribution of all possible outcomes from entrepreneurial action, but does not know which outcome will occur," whereas entrepreneurial uncertainty refers to resource investments (again including the entrepreneur's time and energy) in which the decision maker does not know all possible outcomes from entrepreneurial action and does not know the probability distribution of those outcomes but does know that this information is not known by others (Shepherd, McMullen, \& Jennings, 2007, p. 77). Learning from one's actions is critical to operating in an environment of uncertainty (McGrath, 1999; see also the interactive perspective in Chap. 2). Indeed, learning is considered to be critical in the innovation process (Brown \& Eisenhardt, 1995; Hurley \& Hult, 1998; Nonaka \& Takeuchi, 1995), yet stage-gate controls are believed to restrict learning (Sethi \& Iqbal, 2008). It appears that stage gates are inappropriate for novel or radical innovations (Leifer et al., 2000; McDermott \& O'Connor, 2002; Veryzer, 1998). By pre-specifying the criteria to be used for a go/kill decision at each stage, it is assumed that the process planner 
knows the intended users of the innovation, the benefits the innovation will provide for those users, and ways to competitively position the innovation and the firm (McGrath \& Keil, 2007). However, to the extent that the context is uncertain, these aspects are not known and not knowable (Knight, 1921) at the time of formulating and setting the stage gates.

When the innovation is acted upon, further project information is generated and revealed that helps the innovation process by developing and refining - and possibly redirecting - the potential entrepreneurial opportunity (see also Chap. 2). That is, information about the nature of the potential opportunity and thus the appropriate selection criteria emerge as a result of the innovation process; they are not set prior to its beginning. Therefore, when these criteria are pre-defined, learning is constrained to a narrow path, so the value-creation potential of the opportunity could be lost or substantially curtailed. Therefore, potential opportunities that create value in ways not originally conceived are killed by the formal stagegate process. In this way, decision makers are likely making "premature choices that may not be easily reversible" (Sethi \& Iqbal, 2008, p. 120). That is, once a project is killed, it is likely to be difficult to pick up the project again in the future if the decision makers become aware of the error of their "no go" decision.

Recently, the innovation literature has acknowledged the constraints placed on learning (and the deleterious effects on performance) by stage gates and has proposed that the problem is not so much the stage gates themselves but the people enforcing them. Researchers have argued that it is the rigorous use of gates to control the process that likely causes poor innovation outcomes (Sethi \& Iqbal, 2008). Rigor in gate control refers to "how strictly, how objectively, and consistently, and how frequently criteria are applied (Cooper, 1998, 2001)" (Sethi \& Iqbal, 2008, p. 120). The proposed solution is to make the gates more conditional; with more conditional gates, a project can progress as long as it meets the criteria at the next gate (Cooper, 1994).

However, we know that decision makers are typically biased toward persistence, and the more gates are conditional or malleable, the more decision makers are likely to decide to persist with a poorly performing project. Indeed, there is a substantial literature providing evidence of individuals' (including innovation managers [Patzelt \& Shepherd, 2008]) and organizations' persisting with losing courses of action and even escalating commitment to it (Brockner, 1992; Staw, 1981, 1997; Staw, Barsade, \& Koput, 1997). Biases toward persistence, especially as it relates to stage 
gates, mean that decision makers are likely to lower the hurdle of a particular gate (i.e., exercise the condition of a conditional gate) in their mind, for example, to recoup a return on the time, effort, and money already invested in the entrepreneurial project (i.e., a sunk cost effect) (e.g., Pierce, Kostova, \& Dirks, 2001; Wagner, Parker, \& Christiansen, 2003). Alternatively, they justify the previous decision to start the project, pass it through previous gates, and invest additional resources in its development (i.e., norms for consistency) (Staw, 1981). Finally, there is an expectation that because past projects were successful, the current project will be as well (Audia, Locke, \& Smith, 2000), leading decision makers to become over-confident in the project, the team, and the organization and their ability to "turn this thing around" (Forbes, 2005) and/or leading to a pervasive anti-failure bias (McGrath, 1999).

The above pros and cons of a stage-gate process create a paradox that we, as scholars, still need to work through. The paradox is that on the one hand, the tougher the gates of an innovation process, the less likely there will be persistence with a poorly performing entrepreneurial project, thereby reducing the costs of failure when it eventually occurs. On the other hand, the tougher the stage gates, the less learning that takes place and the less adaptation there is to "new" information generated by the actions within a particular stage, resulting in the premature termination of some valuable projects. Strict stage gates reduce type I errors but increase type II errors.

Because the opportunity underlying the innovation is likely shrouded in uncertainty, it would seem that the information generated through the activities of a stage could be used to choose the criteria for the gate. The purpose of the gate is to still weed out weaker projects, but to be effective, the process needs to be less biased toward persistence; otherwise, the criteria will be chosen and set in a way that ensures the entrepreneurial project passes the gate and moves on to the next stage. Therefore, there is a need for two inter-related streams of research based on the following research questions: (1) How can information (generated by stage activities) be used to select and set criteria for terminating weak entrepreneurial projects and progressing strong entrepreneurial projects? (2) How can this selection process be free of biases toward persistence? Perhaps by addressing the second issue (de-biasing the process), we can gain a deeper understanding of how to achieve the first issue. Indeed, research has investigated reducing or eliminating cognitive biases for different decisions in, for example, health-prevention behaviors (Weinstein \& Klein, 1995), auditing (Kennedy, 1993), litigation (Babcock, Loewenstein, \& Issacharoff, 
1997), and laboratories (Arkes, 1991). Perhaps with additional theorizing, these concepts can be applied or blended for the staged decision making involved in the innovation process and in the development of entrepreneurial projects. We offer four examples below.

\section{Stage Gates and Real Options Reasoning}

Real options reasoning is an approach to making decisions in a way that manages uncertainty. Under real options reasoning, the decision maker invests in a real option that provides him or her the right but not the obligation to continue investment (McGrath, 1996, 1997; McGrath \& Nerkar, 2004). Such an approach requires a mindset that is less focused on achieving success and avoiding failure and more focused on how the two fit together. For example, when one pursues higher-variance entrepreneurial projects, the failure rate will likely increase, but this could lead to highly favorable outcomes if the cost of failure is bounded (McGrath, 1999). When entrepreneurial projects are considered to be a real option, it appears that real options reasoning could be applied to the gate at the end of the first stage of the innovation process. The value of the option is what can be learned at that stage. However, how can real options reasoning be applied to subsequent stages of the innovation process, especially as the investment in the project is greater? Is this greater investment worth it vis-à-vis the project's option value? It would seem that real options reasoning becomes less and less valuable as the entrepreneurial project moves through the stages of innovation because uncertainty is reduced, and option value is lower when uncertainty is lower.

Even if a real options reasoning approach is useful only in the first stage, this first gate is critical to completing the project and reducing the costs of innovation. The mindset underlying real options reasoning fosters learning while preventing a strong commitment to the optioned project. Indeed, this seems to point the way toward a hybrid stage-gate model wherein real options reasoning helps with the go/kill decision at the early stages of the innovation process by enabling learning and flexibility when one makes a decision under high uncertainty. However, for later stages, more focus is given to choosing and setting stage gates because with reduced uncertainty, decision makers are better able to pre-determine the criteria for subsequent gates to manage risk. Further research on this option-stagegate hybrid will likely make an important contribution to the innovation and entrepreneurship literatures. 


\section{Individuals, Learning, and Stage Gates}

Some individuals are better at adapting to changing environments than others. For example, high meta-cognitive awareness-a general level of awareness one has concerning his or her own cognitions focused on a specific entrepreneurial task (Haynie, Shepherd, Mosakowski, \& Earley, 2010 , p. 221) - has been found to facilitate learning and adaptation in schools (Kamp, Admiraal, Drie, \& Rijlaarsdam, 2015; Zohar \& Barzilai, 2013) and in the entrepreneurial context (Haynie, Shepherd, \& Patzelt, 2012). Indeed, superior learning has been associated with numerous cognitive attributes (e.g., learning style [Dunn, Griggs, Olson, Beasley, \& Gorman, 1995], higher-order thinking skills [Zohar \& Dori, 2003], and age [Cross, 1981]), processes (e.g., approaches to learning [Biggs, 1993], spatial transfer [Capello, 1999], and collective learning [Abrahamson \& Fairchild, 1999]), and strategies (e.g., active learning [Meyers \& Jones, 1993], self-regulation [Zimmerman \& Pons, 1986], and peer assistance [Fuchs, Fuchs, Mathes, \& Simmons, 1997]). However, there has been little discussion about decision makers' learning in the stage-gate process. The more we acknowledge the uncertainty surrounding (some) entrepreneurial projects, the more we recognize the importance of learning and adaptive decision making - in selecting and adjusting the gate criteria. In doing so, more scholarly attention is likely to turn to the cognitive processes underlying gate decisions. Some (or perhaps most) gate decisions are made by a team, and there is a substantial literature on collective cognition upon which future stage-gate research can draw to better understand how stage-gate decisions about entrepreneurial projects are made, under what conditions, and to what effect. Such a cognitive explanation of stage gates can also have normative implications as we link cognitive attributes, processes, strategies, and/or collective cognition to value-creation outcomes from the innovation process.

\section{Emotions and the Stage-Gate Process}

Over and above a cognitive perspective, an emotions perspective provides additional insight into stage-gate decisions. For example, people often fear failure (Cacciotti, Hayton, Mitchell, \& Giazitzoglu, 2016; Mitchell \& Shepherd, 2010; Tsai, Chang, \& Peng, 2016). At times, this fear of failure likely manifests itself in a reluctance to kill an entrepreneurial project despite evidence of its weak viability. On the one hand, it could be 
that fear of failure leads to persistence despite poor performance and/or a reluctance to start highly uncertain projects in the first place. On the other hand, a high fear of failure may be more concerned with terminating an entrepreneurial project for large losses than terminating a project for small losses, which may equate to the premature termination of projects (even those that show initial promise). If, as we propose, fear of failure impacts stage-gate decisions, the research focus needs to turn to understanding the causes of these fears, the performance implications of these fears for the firm, and the conditions under which they are magnified or dampened.

There are likely a number of emotions (over and above fear) that influence stage-gate decisions, especially for innovation processes characterized by high uncertainty (e.g., entrepreneurial projects), because in such contexts, individuals often use emotion as a form of information to make decisions (i.e., affect as information) (Forgas, 2001; Marroquín, Boyle, Nolen-Hoeksema, \& Stanton, 2016). These emotions could be negative-such as anxiety (Reiss, 1991; Taylor, 2014), guilt (Block, 2005), and anticipatory grief (Shepherd, Wiklund, \& Haynie, 2009)—and/ or positive-such as passion (Cardon, Wincent, Singh, \& Drnovsek, 2009; Cardon, Zietsma, Saparito, Matherne, \& Davis, 2005), excitement (Klaukien, Shepherd \& Patzelt, 2013), and satisfaction (Breugst \& Shepherd, 2017; Gimeno, Folta, Cooper, \& Woo, 1997). As with the cognitive perspective, scholars can build on emotion research at the individual and team level to better understand the role of collective emotion in the selection and use of stage gates in the termination or progression of entrepreneurial projects through the innovation process.

\section{Organizational Climate and Stage-Gate Decisions}

Organizations and teams can create a climate of psychological safety. Psychological safety refers to "a shared belief held by members of a team that the team is safe for inter-personal risk taking" (Edmondson, 1999, p. 354) and can be promoted in an organization by team leader coaching, the development of high-quality relationships, and commitmentbased human-resources practices (Edmondson, 1999; Edmondson \& Lei, 2014). In a psychologically safe environment, people have greater interpersonal trust and mutual respect (Edmondson, 1999) and are therefore more willing to act creatively (Edmondson \& Lei, 2014), report failures (Cannon \& Edmondson, 2001; Edmondson, 1996), and learn from their actions (Cannon \& Edmondson, 2005; Edmondson, 1999). It is likely 
that many of the biases that lead to persistence can be reduced or avoided through the creation of a psychologically safe organizational environment such that ego-protective mechanisms are no longer needed. For example, in a psychologically safe environment, there will be less need to justify to others previous decisions to start and progress an entrepreneurial project, thus "freeing" the decision maker to terminate a weak project. Similarly, there will be less need to seem consistent such that the decision maker may be more willing to change the criteria for an upcoming gate. Moreover, as others share this psychologically safe environment, they are likely to be more willing to voice concerns (Edmondson \& Lei, 2014) and less likely to penalize those who do, which can have a positive impact on the specifications of stage gates and their use.

We believe that these are conjectures worthy of scholarly investigation. For example, what aspects of a psychologically safe environment reduce the likelihood of persisting with a weak entrepreneurial project? Perhaps the creativity generated in a psychologically safe environment (Gong, Cheung, Wang, \& Huang, 2012) enables greater flexibility in generating gate criteria. It could be that the learning facilitated by psychological safety (Edmondson, 1999) informs the formation or refinement of and/or changes the potential opportunity to enable it to exceed the gate criteria. However, is there a downside to a psychologically safe environment for an entrepreneurial project? Furthermore, while we have highlighted the possibilities of psychological safety, there are other aspects of organizational climate and culture. Organizational climate refers to "the meanings people attach to inter-related bundles of experiences they have at work" (Schneider, Ehrhart, \& Macey, 2013, p. 361), such as procedural justice climate (Naumann \& Bennett, 2000), voice climate (Morrison, Wheeler-Smith, \& Kamdar, 2011), and climates for initiative (Baer \& Frese, 2003). Organizational culture consists of employees' "basic assumptions about their work and the values that guide life in organizations" (Schneider et al., 2013, p. 361) and includes the notions of clan, adhocracy, market, and hierarchy culture (Hartnell \& Walumbwa, 2011)-culture factors that could facilitate the integration of learning into staged decisions in the innovation process.

\section{Summary}

In Fig. 4.2, we offer a sketch of a stage-gate process for entrepreneurial projects. At the start, when managers' uncertainty is high, decision makers use their initial conception of the potential opportunity to create an 


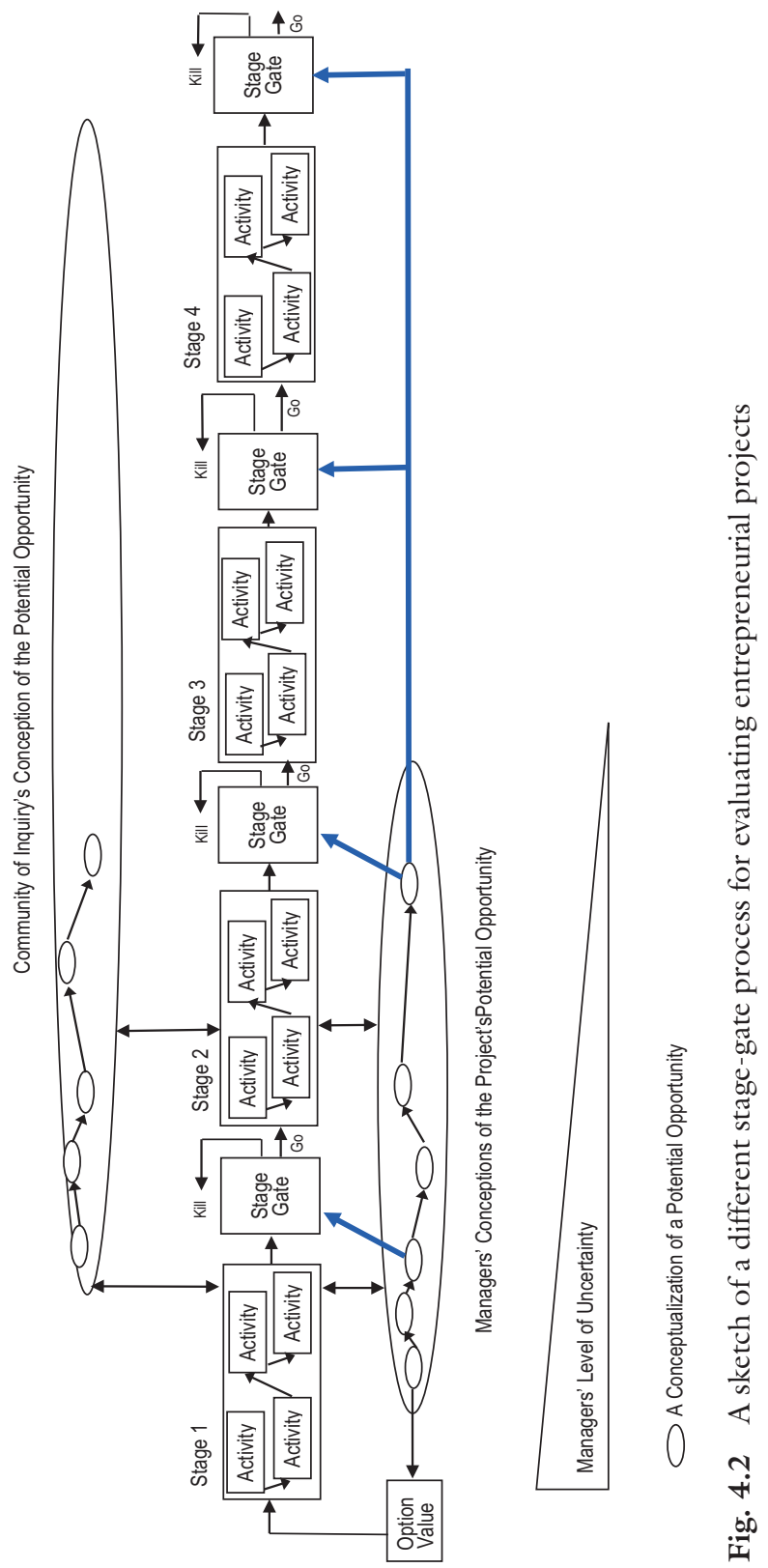


option that initiates the innovation and evaluation process. As the team engages in Stage 1 activities, the information generated leads to changes to the decision makers' initial conceived potential opportunity and to the community of inquiry's (e.g., potential users') conception of the potential opportunity. These conceptions (i.e., of the managers and of the community of inquiry) of the potential opportunity influence the stage's activities, and the stage's activities influence these conceptions. The managers use what they have learned to set a gate for the first stage and thus determine whether the entrepreneurial project should proceed to the next stage (go) or be terminated (kill). Stage 2 requires an additional investment of resources but proceeds like Stage 1 in that activities generate information and conceptions of the opportunity change, thus leading to new or revised activities, all of which further reduce uncertainty. Again, decision makers use their most up-to-date conceptualizations of the opportunity to set the criteria and thresholds for the gate, which determines the go/kill decision. Having substantially reduced uncertainty, the decision makers now set the gates for the remaining stages based on the current conceptualization of the potential opportunity. Once these are set, there are unlikely to be major changes to the nature of the potential opportunity.

\section{Using Operations to “Manage” the Entrepreneurial PROCESS}

Production and operations management generally focuses on the opportunity-exploitation stage; however, such management could also directly inform other stages of the entrepreneurial process as well as enable feedback loops. Operations management refers to "the selection and management of transformation processes that create value for society" (Lovejoy, 1998, p. 106). With this definition as a foundation, operational entrepreneurship can be defined as "the selection and management of transformation processes for recognizing, evaluating, and exploiting opportunities for potential value creation" (Shepherd \& Patzelt, 2013, p. 1416). It is important to note that in line with the definitions of both entrepreneurship and operations management, value creation goes beyond the creation of financial value for the entrepreneur and his or her firm and may also entail financial benefits for others in society or non-financial benefits for the natural and communal environments (Shepherd \& Patzelt, 2011; see also Chap. 5). 
Research on operations management has developed a strong literature on efficient opportunity exploitation in terms of the intermediate and tactical issues related to efficient exploitation. However, we argue that operations management can also be applied to develop a clearer understanding of (1) what knowledge and motivation are needed to identify a potential opportunity, (2) what assessments entrepreneurs make of an identified opportunity to decide whether it represents an opportunity for them specifically, and (3) what influence feedback from the exploitation of a current potential opportunity has on the identification and assessment of subsequent potential opportunities. We now turn to future research paths available at this interface.

\section{Operations Management of Opportunity Identification and Evaluation}

The entrepreneurial process begins when the entrepreneur identifies an opportunity for someone, also known as a third-person opportunity (McMullen \& Shepherd, 2006; e.g., Grégoire \& Shepherd, 2012; Grégoire et al., 2010; Haynie, Shepherd, \& McMullen, 2009). This process of identifying a third-person opportunity happens in an environment characterized by high uncertainty (Knight, 1921; McMullen \& Shepherd, 2006). For instance, an individual may develop a new technology to detoxify water that helps conserve the natural environment. While knowing this new technology is an opportunity that someone can exploit, the individual must decide whether he or she has the knowledge and motivation to exploit the opportunity, which is the next stage of the entrepreneurial process. The ability to focus (the individual or the firm) is a key mechanism underlying why some people are able to identify opportunities while others are not able to or take longer to do so (Bakker \& Shepherd, 2017; Shepherd et al., 2017).

Managing attention to identify opportunities. Previous research has established that individuals (Kahneman, Treisman, \& Gibbs, 1992) and firms (Ocasio, 1997) have limited attention and that this limited attention can lead individuals to develop blind spots, shielding them from detecting information signals about the environment and causing them to miss opportunities (Shepherd et al., 2007, 2016; Tripsas \& Gavetti, 2000; Zahra \& Chaples, 1993). While scholars have explored competitive landscapes (Felin, Kauffman, Koppl, \& Longo, 2014; Levinthal, 1997; Peteraf \& Bergen, 2003) and-to a lesser extent—systematic search for opportu- 
nities (Ardichvili, Cardozo, \& Ray, 2003; Fiet, 2007; Patel \& Fiet, 2009), there is an opportunity to not only gain deeper insights into the ways individuals use attention to detect signals of potential opportunities but also to develop processes that help individuals manage their attention more effectively. These processes, for instance, could include entrepreneurs' building a larger body of prior knowledge that helps them detect environmental signals more readily and, thus, increases their likelihood of identifying an opportunity. In other words, systems that gather, store, and utilize prior market- and technology-related knowledge could improve entrepreneurs' ability to recognize potential opportunities (Grégoire et al., 2010; Shane, 2000; Shepherd \& DeTienne, 2005). A firm's knowledge, for instance, is partially embedded in its manufacturing and/or information technologies (Gaimon, 2008, p. 5). Thus, any innovations related to manufacturing or information technologies signify a "process" opportunity. These process opportunities could in turn represent a dynamic capability as they aid the firm in identifying other potential opportunities. Process improvements like these-including potential enhancements in individuals' ability to recognize opportunities to develop a new product, enter a new market, or improve a process - can stem from changes in manufacturing technology (Boyer \& Lewis, 2002; Gaimon \& Morton, 2005) as well as upgrades in supply chain management systems (Dutta, Lee, \& Whang, 2007; Elmaghraby, 2007), service business models (Kastalli \& Van Looy, 2013), and workforce management techniques (Gaimon, 1997; Vivares, Sarache Castro, \& Naranjo-Valencia, 2016).

Additionally, operational processes could also shed light on why some firms can dedicate more attention to scanning the environment or to initiating creative activities than other firms - that is, the types and nature of their attention structures (Ocasio, 1997). For instance, certain operational processes may be better at facilitating the collection, filtering, and presentation of relevant technology- and market-related information such that decision makers in some firms are given more (or better) opportunityrelated information than their counterparts in other firms. Differences in firms' supply chain management (Helmuth, Craighead, Connelly, Collier, \& Hanna, 2015; Seshadri \& Subrahmanyam, 2005; Tomlin, 2003) could explain why some firms are better at detecting certain environmental signals of potential opportunities; are better at processing information related to a specific technology, market, and/or process challenge; and/or are better at handling the uncertainty and risk inherent in the evaluation and exploitation of potential opportunities. By more deeply exploring the 
processes related to collecting, storing, filtering, and presenting information, operational entrepreneurship researchers can provide practical contributions to help enterprising individuals and firms identify and exploit more opportunities.

Managing motivation for attending to signals of a potential opportunity. Aside from the likely role operational processes play in managing knowledge to increase and focus attentional resources, it is also important to note that motivation has a strong effect on individuals' ability to identify opportunities (Baum \& Locke, 2004; Foo, Uy, \& Murnieks, 2015; Wood, McKelvie, \& Haynie, 2014). Namely, motivation supplies the criteria one needs when determining whether environmental signals indicate an opportunity or merely represent noise-a determination that necessitates judgment (McMullen \& Shepherd, 2006). An individual who is driven by lax criteria will consider more signals to represent potential opportunities; however, an individual driven by strict criteria will consider fewer signals to represent potential opportunities. By following processes prescribed by operational entrepreneurship (including how strict or lax the criteria), entrepreneurs may be able to identify potential opportunities more effectively.

Operational entrepreneurship to collect information to distinguish opportunities from noise. More specifically, to help decide whether a signal represents an opportunity, firms could use operational processes to gather and present information about potential markets, required technologies for the proposed product (e.g., market size, market growth, and technological specifications), and ways to serve customers. For example, knowledge-management systems that assist firms in the creation and storage of technological and market knowledge (Chow, Choy, Lee, \& Chan, 2005; Gunasekaran \& Ngai, 2007) could collect data on past potential opportunities the firm or other firms in the same industry pursued and the success of those exploitations. Such data can be collected from internal sources, external databases, salespeople, industry experts, and so on. In synthesizing and analyzing the data, the systems could then come up with minimum threshold criteria-for example, for the size and growth of a market for the potential opportunity or for the opportunity's compatibility with the technology available to the firm. Perhaps some firms require a high minimum level of technological compatibility (i.e., strict criteria), whereas others require a low minimum level of technological compatibility (i.e., lax criteria). It could be interesting to explore what types of data should be collected and analyzed (and how) to effectively determine 
potential criteria for identifying potential opportunities and how they are used to distinguish signals of opportunity from noise.

Operational entrepreneurship to use motivation to classify what signifies exploitable opportunities and what signifies noise. There are substantial differences across firms in terms of how much and how effectively knowledge-management systems are applied depending on the firm's culture, leadership, reward and incentive systems, and values and norms (Lai \& Chu, 2002). These differences suggest that a match between decision makers' motivation and the results of a system's data analysis is important for decision makers to identify an actionable opportunity rather than an opportunity that they are less motivated to exploit. How can such a match be achieved? For example, decision-support systems based on artificial intelligence, such as those used for location choices (Kuo, Chi, \& Kao, 2002) or strategic planning (Pinson, Louçã, \& Moraitis, 1997), can learn decision makers' preferences over time, which helps them identify the "right" opportunities that match their motivation and preferences. Interesting research is likely to come from applying such systems and exploring the boundaries of their application (e.g., decision makers' irrational assessments and biases).

Operational entrepreneurship can help individuals choose and manage processes that regulate the payoffs for entrepreneurial action. The payoffs for entrepreneurial action include, exploiting a potential opportunity and being right, exploiting a potential opportunity and being wrong, not exploiting a potential opportunity and being right, and not exploiting a potential opportunity and being wrong. For example, operations management research has drawn on simulation techniques for profitability analysis (Montes, Martin, Bayo, \& Garcia, 2011; Song \& Kim, 2001) and has analyzed the consequences of supply chain failures (Kull \& Closs, 2008). Perhaps these systems can serve as a basis for developing simulation processes for the type I and type II errors resulting from exploiting a potential opportunity. Such simulation tools seem to have the potential to substantially improve, advance, change, or supplement the ways individuals and/or organizations assess potential opportunities.

Operational entrepreneurship to determine the sensitivity of payoffs by considering (1) the decreased likelihood of errors of commission and omission due to the added information that could be obtained by postponing opportunity exploitation for a period, (2) the likelihood that a window of opportunity will close from a delay in opportunity exploitation, and/or (3) the outcomes that would occur from varying the criteria 
in terms of being more lax or more strict. Again, building on operations research's tradition of developing and using simulation methods might be a valuable approach. A central strength of these methods is that they allow for experimentation; that is, researchers can systematically vary input opportunity parameters (Davis, Bingham, \& Eisenhardt, 2007), such as raw material prices, market size, market growth, lead time, technological developments, prices, and so on. Based on these variations, the simulation can compute the payoffs of pursuing, not pursuing, or postponing the pursuit of a potential opportunity. Moreover, fixing certain parameters to more conservative values (e.g., minimum market size) in a number of simulations might represent a strict criterion that can be relaxed in additional simulations.

Challenges for operational entrepreneurship in facilitating opportunity identification. Despite the benefits it is likely to bring, there are several challenges associated with operational entrepreneurship stemming from the uncertainty and complexity inherent in information surrounding potential opportunities (Knight, 1921; McMullen \& Shepherd, 2006). For example, entrepreneurs who develop radical innovations often decide not to enter established markets but to instead create new markets (O'Connor, 1998; Santos \& Eisenhardt, 2009). Information for these markets is generally not readily available (O'Connor \& Veryzer, 2001), thus making it challenging for operational entrepreneurship scholars to create systems that help entrepreneurs identify potential opportunities for radically new technologies. Furthermore, the payoffs of entrepreneurial action vary and include financial costs and benefits as well as non-financial motivational and emotional payoffs. For instance, many entrepreneurs are motivated by independence (McMullen, Bagby, \& Palich, 2008), passion (Cardon et al., 2005), and the need for achievement (Shane, Locke, \& Collins, 2003), all of which are challenging to quantitatively evaluate. In addition, sustainable and social entrepreneurs frequently have strong environmental and altruistic motivations (Mair \& Marti, 2006; Miller, Grimes, McMullen, \& Vogus, 2012; Patzelt \& Shepherd, 2010; Peredo \& Chrisman, 2006), which are, again, challenging to operationalize in quantitative terms.

While such challenges are unlikely to be resolved entirely to the point that "optimal" decisions can be made, operational entrepreneurship research can still be beneficial in this context by clarifying the inputs (e.g., collecting additional information, understanding complexity, and making the criteria and their outcomes clear) entrepreneurs use to form judg- 
ments and then communicate those judgments to others. This type of research would likely further develop and expand current operations management research on the various forms of uncertainty entrepreneurs and entrepreneurial firms face in the new product development process (e.g., market, creative, and process uncertainty [Anderson \& Joglekar, 2005]) and methods to handle these uncertainties, including, for example, flexible manufacturing capacity (Fine \& Freund, 1990), trial-and-error learning or real options reasoning (Sommer \& Loch, 2004), supplier selection (Riedl, Kaufmann, Zimmermann, \& Perols, 2013; Simangunsong, Hendry, \& Stevenson, 2016), and maybe even supply chain management (Seshadri \& Subrahmanyam, 2005; Tomlin, 2003).

\section{Operations Management of Opportunity Exploitation}

While an individual's identification of a potential opportunity is essential for entrepreneurial action, it is not the only requirement; the entrepreneur or entrepreneurial firm also needs to decide whether the third-person opportunity at hand is a first-person opportunity (i.e., determine that this opportunity for someone is an opportunity for him or her [or the firm]) (McMullen \& Shepherd, 2006). This has some interesting implications for blending operations management constructs and new entrepreneurial constructs.

Operations management when the opportunity is the firm. The operations management literature includes numerous studies exploring effective and efficient opportunity exploitation in established firms (e.g., Kavadias \& Loch, 2003). However, investigating effective and efficient opportunity exploitation becomes more challenging when the particular opportunity necessitates the creation of a new firm. In this case, the potential opportunity is the firm, and the firm is the potential opportunity. Thus, a significant question remains: How is the operations management of the exploitation of a potential opportunity different in new firms than in existing firms? Many important differences are likely to exist between the two types of firms as a new firm is predominately a "blank slate." While new firms can develop operational processes that are tailored to the opportunity at hand, they are unable to take stock of existing operational processes and alter them as needed to act on the opportunity. Thus, starting a new firm necessitates a holistic approach to operations management as opposed to a targeted specialized approach. More specifically, instead of solving an operations management problem, operational entrepreneur- 
ship for new firms entails finding concurrent solutions for numerous operations challenges. Although operations management scholars are highly skilled at resolving concurrent issues for a problem within one part of an existing firm, operational entrepreneurship scholars who are able to overcome the challenge of simultaneously developing all operational processes in a new firm will contribute substantially to the entrepreneurship and operations management literatures.

Feedback loops arising from the exploitation of a potential opportunity. Exploiting a specific potential opportunity can reveal information (some of which is only available after action has been taken) that plays a part in altering the existing potential opportunity and/or identifying another potential opportunity. For instance, systems that gather, filter, and store stakeholders' (including customers') feedback on a new product or service and then present that information to decision makers can impact those decision makers' knowledge and desire to direct their attention to particular aspects of their business and/or the natural and communal environments. Feedback from scientific research, for instance, can change an entrepreneur's search processes "by leading them more directly to useful combinations, eliminating fruitless paths of research, and motivating them to continue even in the face of negative feedback [from other sources]" (Fleming \& Sorenson, 2004, p. 909). Future operational entrepreneurship research can explore what processes and systems need to be developed to effectively capture and make use of information resulting from the exploitation of potential opportunities and to improve (i.e., inform and/ or motivate) entrepreneurs' ability to refine those potential opportunities and/or act upon subsequent potential opportunities.

Exploiting a potential opportunity has the potential to alter the viability and appeal of that particular potential opportunity or of later potential opportunities. More specifically, opportunity exploitation may modify how entrepreneurs or firms assess third-person opportunities to decide whether they are (or continue to be) first-person opportunities. Exploiting a particular potential opportunity, for instance, may help individuals or firms gain experience, skills, and/or capabilities that must be taken into account when they evaluate the viability of future potential opportunities (e.g., learning's influence on make or buy decisions [Anderson \& Parker, 2002]). In a similar way, going through the opportunity-exploitation process and/or having (or not having) success in doing so may alter how appealing one finds the prospect of exploiting future potential opportunities. Such effects have clear implications for 
the discussion on opportunity evaluation we outlined above. However, if changes like these are expected to be large and occur frequently, a more dynamic system is necessary. Future research in this area can build on the current research stream exploring learning in and about complex dynamic systems (see Rahmandad, 2008; Sterman, 2000a, 2000b) as well as dynamic processes for new product development (Anderson \& Joglekar, 2005; Brown \& Eisenhardt, 1997).

Summary. In Fig. 4.3, we offer a sketch on the role of operations management in the formation of opportunity beliefs. We start with the base model in which (1) knowledge decreases the amount of uncertainty to facilitate the formation of opportunity beliefs (both third- and firstperson beliefs) and (2) motivation increases the willingness to bear uncertainty to facilitate the formation of opportunity beliefs (both third- and first-person beliefs). Operations management likely plays a role in this process. More specifically, operations management can enhance information search (i.e., more effective and efficient collection, storage, and use of information) to reduce the level of uncertainty that might have otherwise contributed doubt about a potential opportunity. Decision aids weight criteria as a reflection of the decision makers' motivation, and the decision makers' motivation can influence their willingness to bear uncertainty in the formation of opportunity beliefs (both thirdand first-person beliefs). Information systems, decision aids, and other forms of current operations focus decision makers' attention, which in turn impacts the identification and evaluation of potential opportunities. As operations management focuses on decision makers' attention, this will influence their knowledge accumulation and motivation. The identification of a potential opportunity (third-person opportunity belief) and its evaluation (first-person opportunity belief) also influence knowledge accumulation and motivation. Therefore, operations management not only reflects knowledge and motivation but also influences through both decision makers' attentional focus and the formation of opportunity beliefs.

\section{Discussion And Conclusion}

In this chapter, we elaborated on research opportunities emerging from literatures that show considerable similarity to and overlap with the entrepreneurship literature. However, in the past, this overlap has largely been ignored, and thus, a host of research opportunities have gone unheeded. 


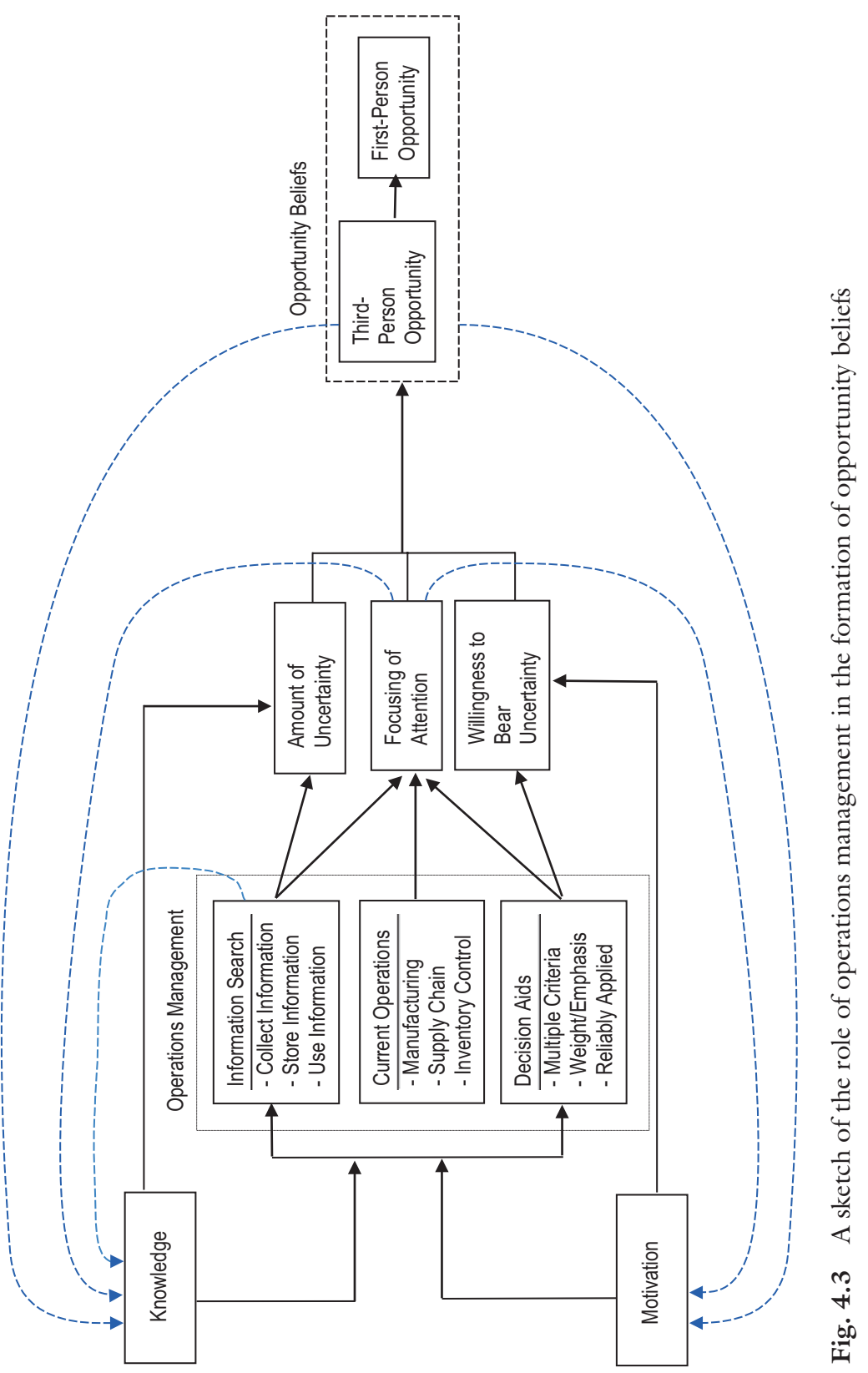


Specifically, we believe that research at the intersections of the literatures on ACAP, innovation, and operations research represents substantial potential to advance entrepreneurship theory.

First, our discussion highlights the complementarity between models of entrepreneurial action and the concept of ACAP in terms of the common emphasis on knowledge - either at the individual level or at the organizational level. When potential opportunities are developed and refined based on interactions with a social environment (e.g., Dimov, 2007; Shepherd, 2015), the information received from that environment is "filtered" based on the entrepreneur's or the venture's ACAP, thus influencing the future development of the potential opportunity. In turn, ACAP is developed through knowledge acquired based on feedback on the potential opportunity from the entrepreneurial environment. Given this mutual influence of an entrepreneurial actor's ACAP and opportunity development, it seems surprising that prior research has made little effort to integrate both literatures. We hope that our discussion on the multi-dimensional nature of ACAP in the entrepreneurial context provides a starting point for such efforts.

Second, in the context of innovation, we believe that taking an entrepreneurship perspective on stage-gate processes used to judge projects under development can yield significant new insights. Because entrepreneurial projects are shrouded in uncertainty with little information available about potential outcomes or about the likelihood that these outcomes will be reached, it appears that the stage-gate process as described in the innovation literature might reach its limits when it comes to managing entrepreneurial projects. Specifically, it seems crucial for future research to resolve the paradox of setting tough stage gates to prevent biased decision making (e.g., escalation of commitment) on the one hand and setting less strict stage gates to facilitate learning on the other hand. We offer three potential ways forward: (1) adapting stage gates throughout the innovation process (i.e., more flexible at the beginning and more strict at the end); (2) taking into account individual characteristics that make decision makers more or less prone to biases (i.e., cognitions and emotions); and (3) taking into account organizational characteristics, particularly a climate of psychological safety. We hope scholars will explore how these factors - as well as others (e.g., product characteristics) — can contribute to adapting the stage-gate process so that entrepreneurial (rather than incrementally innovative) projects can be managed effectively for the benefit of the organization as a whole. 
Third, the literature on operations management might provide new insights into how to manage the identification and exploitation of entrepreneurial opportunities. This literature has a long tradition of exploring the effective and efficient use of knowledge-management systems (e.g., Chow et al., 2005; Gunasekaran \& Ngai, 2007), and given the importance of knowledge for opportunity identification and exploitation, it seems reasonable to assume that such systems can complement the entrepreneurial process. In addition, the more recent development of systems based on artificial intelligence (e.g., Kuo et al., 2002; Pinson et al., 1997) and simulation techniques (e.g., Kull \& Closs, 2008; Montes et al., 2011; Song \& Kim, 2001) can provide tools that (corporate) entrepreneurs can use to make better decisions in terms of both creating optimal outputs for the firm and matching decision makers' preferences to potential opportunities. However, few entrepreneurship scholars have studied the (potential) role of these computer-based systems in the entrepreneurial process or their complementarities and interactions. Given the increasing digitalization of business and organizational environments, we believe there are many ways future research in this area can advance our understanding of entrepreneurial phenomena.

To conclude, taking a look at neighboring but largely parallel literatures is an important way to extend the boundaries of entrepreneurship theory. We offer three literatures that seem to represent exciting future research opportunities when viewed through an entrepreneurship lens and hope that scholars from either entrepreneurship or one of these disciplines are inspired by our discussion.

\section{REFERENCES}

Abernathy, W. J., \& Utterback, J. M. (1978). Patterns of industrial innovation. Technology Review, 64(7), 254-228.

Abrahamson, E., \& Fairchild, G. (1999). Management fashion: Lifecycles, triggers, and collective learning processes. Administrative Science Quarterly, 44(4), 708-740.

Adner, R., \& Levinthal, D. A. (2004). What is not a real option: Considering boundaries for the application of real options to business strategy. Academy of Management Review, 29(1), 74-85.

Allen, T. J. (1977). Managing the flow of technology: Technology transfer and the dissemination of technological information within the $R$ and $D$ organization. Cambridge, MA: MIT Press. 
Anderson, E. G., \& Joglekar, N. R. (2005). A hierarchical product development planning framework. Production and Operations Management, 14(3), 344-361.

Anderson, E. G., \& Parker, G. G. (2002). The effect of learning on the make/buy decision. Production \& Operations Management, 11(3), 313-339.

Ardichvili, A., Cardozo, R., \& Ray, S. (2003). A theory of entrepreneurial opportunity identification and development. Journal of Business Venturing, 18(1), $105-123$.

Arkes, H. R. (1991). Costs and benefits of judgment errors: Implications for debiasing. Psychological Bulletin, 110(3), 486-498.

Atuahene-Gima, K. (1996). Market orientation and innovation. Journal of Business Research, 35(2), 93-103.

Audia, P. G., Locke, E. A., \& Smith, K. G. (2000). The paradox of success: An archival and a laboratory study of strategic persistence following radical environmental change. Academy of Management Journal, 43(5), 837-853.

Babcock, L., Loewenstein, G., \& Issacharoff, S. (1997). Creating convergence: Debiasing biased litigants. Law \& Social Inquiry, 22(4), 913-925.

Baer, M., \& Frese, M. (2003). Innovation is not enough: Climates for initiative and psychological safety, process innovations, and firm performance. Journal of Organizational Behavior, 24(1), 45-68.

Baker, T., \& Nelson, R. E. (2005). Creating something from nothing: Resource construction through entrepreneurial bricolage. Administrative Science Quarterly, 50(3), 329-366.

Bakker, R. M., \& Shepherd, D. A. (2017). Pull the plug or take the plunge: Multiple opportunities and the speed of venturing decisions in the Australian mining industry. Academy of Management Journal.

Baum, J. R., \& Locke, E. A. (2004). The relationship of entrepreneurial traits, skill, and motivation to subsequent venture growth. Journal of Applied Psychology, 89(4), 587-598.

Behrens, J., \& Ernst, H. (2014). What keeps managers away from a losing course of action? Go/stop decisions in new product development. Journal of Product Innovation Management, 31(2), 361-374.

Behrens, J., \& Patzelt, H. (2017). Corporate entrepreneurship managers' project terminations: Integrating portfolio-level, individual-level, and firm-level effects. Entrepreneurship Theory and Practice. Forthcoming.

Benner, M. J., \& Tushman, M. L. (2003). Exploitation, exploration, and process management: The productivity dilemma revisited. Academy of Management Review, 28(2), 238-256.

Biggs, J. (1993). What do inventories of students' learning processes really measure? A theoretical review and clarification. British Journal of Educational Psychology, 63(1), 3-19.

Block, L. G. (2005). Self-referenced fear and guilt appeals: The moderating role of self-construal. Journal of Applied Social Psychology, 35(11), 2290-2309. 
Boulding, W., Morgan, R., \& Staelin, R. (1997). Pulling the plug to stop the new product drain. Journal of Marketing Research, 34(1), 164-176.

Boyer, K., \& Lewis, M. W. (2002). Competitive priorities: Investigating the need for trade-offs in operations strategy. Production and Operations Management, 11(1), 9-20.

Bradley, S. W., Aldrich, H., Shepherd, D. A., \& Wiklund, J. (2011). Resources, environmental change, and survival: Asymmetric paths of young independent and subsidiary organizations. Strategic Management Journal, 32(5), 486-509.

Breugst, N., \& Shepherd, D. A. (2017). If you fight with me, I'll get mad! A social model of entrepreneurial affect. Entrepreneurship Theory and Practice.

Brockner, J. (1992). The escalation of commitment to a failing course of action: Toward theoretical progress. Academy of Management Review, 17(1), 39-61.

Brown, S. L., \& Eisenhardt, K. M. (1995). Product development: Past research, present findings, and future directions. Academy of Management Review, 20(2), 343-378.

Brown, S. L., \& Eisenhardt, K. M. (1997). The art of continuous change: Linking complexity theory and time-paced evolution in relentlessly shifting organizations. Administrative Science Quarterly, 42, 1-34.

Burgelman, R. A. (1983). Corporate entrepreneurship and strategic management: Insights from a process study. Management Science, 29(12), 1349-1364.

Burgelman, R. A. (1984). Designs for corporate entrepreneurship in established firms. California Management Review, 26(3), 154-166.

Cacciotti, G., Hayton, J. C., Mitchell, J. R., \& Giazitzoglu, A. (2016). A reconceptualization of fear of failure in entrepreneurship. Journal of Business Venturing, 31(3), 302-325.

Cannon, M. D., \& Edmondson, A. C. (2001). Confronting failure: Antecedents and consequences of shared beliefs about failure in organizational work groups. Journal of Organizational Behavior, 22(2), 161-177.

Cannon, M. D., \& Edmondson, A. C. (2005). Failing to learn and learning to fail (intelligently): How great organizations put failure to work to innovate and improve. Long Range Planning, 38(3), 299-319.

Capello, R. (1999). Spatial transfer of knowledge in high technology milieux: Learning versus collective learning processes. Regional Studies, 33(4), 353-365.

Capon, N., Farley, J. U., \& Hoenig, S. (1990). Determinants of financial performance: A meta-analysis. Management Science, 36(10), 1143-1159.

Cardon, M. S., Wincent, J., Singh, J., \& Drnovsek, M. (2009). The nature and experience of entrepreneurial passion. Academy of Management Review, 34(3), $511-532$.

Cardon, M. S., Zietsma, C., Saparito, P., Matherne, B. P., \& Davis, C. (2005). A tale of passion: New insights into entrepreneurship from a parenthood metaphor. Journal of Business Venturing, 20(1), 23-45.

Chaudhuri, S., \& Tabrizi, B. (1999). Capturing the real value in high-tech acquisitions. Harvard Business Review, 77(5), 123-130. 
Chow, H. K., Choy, K. L., Lee, W. B., \& Chan, F. T. (2005). Design of a knowledge-based logistics strategy system. Expert Systems with Applications, 29(2), 272-290.

Christensen, C. M., \& Bower, J. L. (1996). Customer power, strategic investment, and the failure of leading firms. Strategic Management Journal, 17(3), 197-218.

Cockburn, I., \& Henderson, R. (1998). Absorptive capacity, co-authoring behavior, and the organization of research in drug discovery. Journal of Industrial Economics., 46, 157-183.

Cohen, W. M., \& Levinthal, D. A. (1990). Absorptive capacity: A new perspective on learning and innovation. Administrative Science Quarterly, 35(1), 128-152.

Cooper, R. G. (1994). Third-generation new product processes. Journal of Product Innovation Management, 11(1), 3-14.

Cooper, R. G. (1998). Product leadership: Creating and launching superior new products. Reading, MA: Perseus Books.

Cooper, R. G. (2001). Winning at new products: Accelerating the process from idea to launch. New York: Perseus Publishing.

Cooper, R. G. (2008). Perspective: The stage-gate ${ }^{\circledR}$ idea-to-launch processUpdate, what's new, and nexgen systems. Journal of Product Innovation Management, 25(3), 213-232.

Cooper, R. G. (2013). Where are all the breakthrough new products?: Using portfolio management to boost innovation. Research-Technology Management, $56(5), 25-33$.

Cooper, R. G., Edgett, S. J., \& Kleinschmidt, E. J. (2002). Optimizing the stagegate process: What best-practice companies do. Research-Technology Management, 45(5), 21-27.

Cooper, R. G., \& Kleinschmidt, E. J. (1993). Major new products: What distinguishes the winners in the chemical industry? Journal of Product Innovation Management, 10(2), 90-111.

Covin, J. G., \& Miles, M. P. (1999). Corporate entrepreneurship and the pursuit of competitive advantage. Entrepreneurship Theory and Practice, 23(3), $47-47$.

Covin, J. G., \& Slevin, D. P. (1989). Strategic management of small firms in hostile and benign environments. Strategic Management Journal, 1O(1), 75-87.

Cross, K. P. (1981). Adults as learners. Increasing participation and facilitating learning. ERIC. San Francisco, CA: Jossey-Bass, Inc.

Damanpour, F. (1991). Organizational innovation: A meta-analysis of effects of determinants and moderators. Academy of Management Journal, 34(3), $555-590$.

Davis, J. P., Bingham, C. B., \& Eisenhardt, K. M. (2007). Developing theory from simulation models. Academy of Management Review, 32, 480-499.

Dewar, R. D., \& Dutton, J. E. (1986). The adoption of radical and incremental innovations: An empirical analysis. Management Science, 32(11), 1422-1433. 
Dimov, D. (2007). Beyond the single-person, single-insight attribution in understanding entrepreneurial opportunities. Entrepreneurship Theory and Practice, 31(5), 713-731.

Domurath, A., \& Patzelt, H. (2016). Entrepreneurs' assessments of early international entry: The role of foreign social ties, venture absorptive capacity, and generalized trust in others. Entrepreneurship Theory \& Practice, 40(5), 1149-1177.

Dunn, R., Griggs, S. A., Olson, J., Beasley, M., \& Gorman, B. S. (1995). A metaanalytic validation of the Dunn and Dunn model of learning-style preferences. The Journal of Educational Research, 88(6), 353-362.

Dutta, A., Lee, H. L., \& Whang, S. (2007). RFID and operations management: Technology, value, and incentives. Production and Operations Management, $16(5), 646-655$.

Edmondson, A. C. (1996). Learning from mistakes is easier said than done: Group and organizational influences on the detection and correction of human error. The Journal of Applied Behavioral Science, 32(1), 5-28.

Edmondson, A. C. (1999). Psychological safety and learning behavior in work teams. Administrative Science Quarterly, 44(2), 350-383.

Edmondson, A. C., \& Lei, Z. (2014). Psychological safety: The history, renaissance, and future of an interpersonal construct. Annual Review of Organizational Psychology and Organizational Behavior, 1(1), 23-43.

Eisenhardt, K. M., \& Martin, J. A. (2000). Dynamic capabilities: What are they? Strategic Management Journal, 21(10-11), 1105-1121.

Elmaghraby, W. (2007). Auctions within e-sourcing events. Production and Operations Management, 16(4), 409-422.

Ettlie, J. E., Bridges, W. P., \& O'keefe, R. D. (1984). Organization strategy and structural differences for radical versus incremental innovation. Management Science, 30(6), 682-695.

Felin, T., Kauffman, S., Koppl, R., \& Longo, G. (2014). Economic opportunity and evolution: Beyond landscapes and bounded rationality. Strategic Entrepreneurship Journal, 8(4), 269-282.

Fiet, J. O. (2007). A prescriptive analysis of search and discovery. Journal of Management Studies, 44(4), 592-611.

Fine, C., \& Freund, R. (1990). Optimal investment in product flexible manufacturing capacity. Management Science, 36(4), 449-466.

Fleming, L., \& Sorenson, O. (2004). Science as a map in technological research. Strategic Management Journal, 25(8-9), 909-928.

Foo, M. D., Uy, M. A., \& Murnieks, C. (2015). Beyond affective valence: Untangling valence and activation influences on opportunity identification. Entrepreneurship Theory and Practice, 39(2), 407-431.

Forbes, D. P. (2005). Are some entrepreneurs more overconfident than others? Journal of Business Venturing, 20(5), 623-640. 
Forgas, J. P. (2001). Feeling and thinking: The role of affect in social cognition. Cambridge: Cambridge University Press.

Fuchs, D., Fuchs, L. S., Mathes, P. G., \& Simmons, D. C. (1997). Peer-assisted learning strategies: Making classrooms more responsive to diversity. American Educational Research Journal, 34(1), 174-206.

Gaimon, C. (1997). Planning information technology-knowledge worker systems. Management Science, 43(9), 1308-1328.

Gaimon, C. (2008). The management of technology: A production and operations management perspective. Production and Operations Management, 17(1), $1-11$.

Gaimon, C., \& Morton, A. (2005). Investment in facility changeover flexibility for early entry into high-tech markets. Production and Operations Management, 14(2), 159-174.

Galunic, D. C., \& Eisenhardt, K. M. (2001). Architectural innovation and modular corporate forms. Academy of Management journal, 44(6), 1229-1249.

Gimeno, J., Folta, T. B., Cooper, A. C., \& Woo, C. Y. (1997). Survival of the fittest? Entrepreneurial human capital and the persistence of underperforming firms. Administrative Science Quarterly, 42, 750-783.

Gong, Y., Cheung, S. Y., Wang, M., \& Huang, J. C. (2012). Unfolding the proactive process for creativity integration of the employee proactivity, information exchange, and psychological safety perspectives. Journal of Management, 38(5), $1611-1633$.

Grégoire, D. A., Barr, P. S., \& Shepherd, D. A. (2010). Cognitive processes of opportunity recognition: The role of structural alignment. Organization Science, 21(2), 413-431.

Grégoire, D. A., \& Shepherd, D. A. (2012). Technology-market combinations and the identification of entrepreneurial opportunities: An investigation of the opportunity-individual nexus. Academy of Management Journal, 55(4), 753-785.

Gunasekaran, A., \& Ngai, E. W. T. (2007). Knowledge management in twentyfirst century manufacturing. International Journal of Production Research, 45(11), 2391-2418.

Hart, S. L., \& Milstein, M. B. (2003). Creating sustainable value. Academy of Management Executive, 17(2), 56-67.

Hartnell, C. A., \& Walumbwa, F. O. (2011). Transformational leadership and organizational culture. In N. M. Ashkanasy, C. P. M. Wilderom, \& M. F. Peterson (Eds.), The handbook of organizational culture and climate (pp. 225-248). Thousand Oaks, CA: Sage Publications.

Haynie, J. M., Shepherd, D. A., \& McMullen, J. S. (2009). An opportunity for me? The role of resources in opportunity evaluation decisions. Journal of Management Studies, 46(3), 337-361.

Haynie, J. M., Shepherd, D. A., Mosakowski, E., \& Earley, P. C. (2010). A situated metacognitive model of the entrepreneurial mindset. Journal of Business Venturing, 25(2), 217-229. 
Haynie, J. M., Shepherd, D. A., \& Patzelt, H. (2012). Cognitive adaptability and an entrepreneurial task: The role of metacognitive ability and feedback. Entrepreneurship Theory and Practice, 36(2), 237-265.

Helmuth, C. A., Craighead, C. W., Connelly, B. L., Collier, D. Y., \& Hanna, J. B. (2015). Supply chain management research: Key elements of study design and statistical testing. Journal of Operations Management, 36, 178-186.

Henderson, R. M., \& Clark, K. B. (1990). Architectural innovation: The reconfiguration of existing product technologies and the failure of established firms. Administrative Science Quarterly, 35(1), 9-30.

Hull, C. E., \& Rothenberg, S. (2008). Firm performance: The interactions of corporate social performance with innovation and industry differentiation. Strategic Management Journal, 29(7), 781-789.

Hurley, R. F., \& Hult, G. T. M. (1998). Innovation, market orientation, and organizational learning: An integration and empirical examination. The Journal of Marketing, 62(3), 42-54.

Kahneman, D., Treisman, A., \& Gibbs, B. (1992). The reviewing of object files: Object-specific integration of information. Cognitive Psychology, 24(2), 175-219.

Kamp, M. T., Admiraal, W., Drie, J., \& Rijlaarsdam, G. (2015). Enhancing divergent thinking in visual arts education: Effects of explicit instruction of metacognition. British Journal of Educational Psychology, 85(1), 47-58.

Kastalli, I. V., \& Van Looy, B. (2013). Servitization: Disentangling the impact of service business model innovation on manufacturing firm performance. Journal of Operations Management, 31(4), 169-180.

Katz, J., \& Gartner, W. B. (1988). Properties of emerging organizations. Academy of Management Review, 13(3), 429-441.

Kavadias, S., \& Loch, C. H. (2003). Optimal project sequencing with recourse at a scarce resource. Production and Operations Management, 12(4), 433-444.

Kennedy, J. (1993). Debiasing audit judgment with accountability: A framework and experimental results. Journal of Accounting Research, 31(2), 231-245.

Khazanchi, S., Lewis, M. W., \& Boyer, K. K. (2007). Innovation-supportive culture: The impact of organizational values on process innovation. Journal of Operations Management, 25(4), 871-884.

Kim, L. (1997a). The dynamics of Samsung's technological learning in semiconductors. California Management Review, 39(3), 86-100.

Kim, L. (1997b). From imitation to innovation: The dynamics of Korea's technological learning. Cambridge, MA: Harvard Business School Press.

Klaukien, A., Shepherd, D. A., \& Patzelt, H. (2013). Passion for work, nonworkrelated excitement, and innovation managers' decision to exploit new product opportunities. Journal of Product Innovation Management, 30(3), 574-588.

Klingebiel, R., \& Rammer, C. (2014). Resource allocation strategy for innovation portfolio management. Strategic Management Journal, 35(2), 246-268. 
Knight, F. H. (1921). Risk, uncertainty and profit. New York: Hart, Schaffner and Marx.

Kull, T., \& Closs, D. (2008). The risk of second-tier supplier failures in serial supply chains: Implications for order policies and distributor autonomy. European Journal of Operational Research, 186(3), 1158-1174.

Kuo, R. J., Chi, S. C., \& Kao, S. S. (2002). A decision support system for selecting convenience store location through integration of fuzzy AHP and artificial neural network. Computers in Industry, 47(2), 199-214.

Lai, H., \& Chu, T. H. (2002). Knowledge management: A review of industrial cases. Journal of Computer Information Systems, 42(5), 26-39.

Lane, P. J., \& Lubatkin, M. (1998). Relative absorptive capacity and interorganizational learning. Strategic Management Journal, 19(5), 461-477.

Leifer, R., McDermott, C. M., O’Connor, G. C., Peters, L. S., Rice, M. P., \& Veryzer, R. W. (2000). Radical innovation: How mature companies can outsmart upstarts. Boston, MA: Harvard Business School Press.

Levinthal, D. A. (1997). Adaptation on rugged landscapes. Management Science, $43(7), 934-950$.

Li, H., \& Atuahene-Gima, K. (2001). Product innovation strategy and the performance of new technology ventures in China. Academy of Management Journal, 44(6), 1123-1134.

Lichtenstein, B. B., Dooley, K. J., \& Lumpkin, G. T. (2006). Measuring emergence in the dynamics of new venture creation. Journal of Business Venturing, $21(2), 153-175$.

Lofstrom, S. M. (2000). Absorptive capacity in strategic alliances: Investigating the effects of individuals' social and human capital on inter-firm learning. Paper presented at the Organization Science Winter Conference, Keystone, CO.

Lovejoy, W. S. (1998). Integrated operations: A proposal for operations management teaching and research. Production and Operations Management, 7(2), 106-124.

Lyles, M. A., \& Schwenk, C. R. (1992). Top management, strategy and organizational knowledge structures. Journal of Management Studies, 29(2), 155-174.

Marroquín, B., Boyle, C. C., Nolen-Hoeksema, S., \& Stanton, A. L. (2016). Using emotion as information in future-oriented cognition: Individual differences in the context of state negative affect. Personality and Individual Differences, 95, 121-126.

Mair, J., \& Marti, I. (2006). Social entrepreneurship research: A source of explanation, prediction, and delight. Journal of World Business, 4l(1), 36-44.

Matusik, S. F. (2000). Absorptive capacity and firm knowledge: Separating the effects of public knowledge, flexible firm boundaries, and firm absorptive abilities. Paper presented at the Organization Science Winter Conference, Keystone, CO. 
Matusik, S. F., \& Heeley, M. (2001). Absorptive capacity and firm knowledge: Separating the multiple components of the absorptive capacity construct. Paper presented at the annual meeting of the Academy of Management, Washington, DC.

McDermott, C. M., \& O'Connor, G. C. (2002). Managing radical innovation: An overview of emergent strategy issues. Journal of Product Innovation Management, 19(6), 424-438.

McGrath, R. G. (1996). Options and the enterprise: Toward a strategic theory of entrepreneurial wealth creation. Academy of Management Proceedings, 1 , 101-105.

McGrath, R. G. (1997). A real options logic for initiating technology positioning investments. Academy of Management Review, 22(4), 974-996.

McGrath, R. G. (1999). Falling forward: Real options reasoning and entrepreneurial failure. Academy of Management Review, 24(1), 13-30.

McGrath, R. G., \& Keil, T. (2007). The value captor's process: Getting the most out of your new business ventures. Harvard Business Review, 85(5), $128-136$.

McGrath, R. G., \& MacMillan, I. C. (2000). The entrepreneurial mindset: Strategies for continuously creating opportunity in an age of uncertainty (Vol. 284). Boston, MA: Harvard Business Press.

McGrath, R. G., \& Nerkar, A. (2004). Real options reasoning and a new look at the R\&D investment strategies of pharmaceutical firms. Strategic Management Journal, 25(1), 1-21.

McMullen, J. S., Bagby, D., \& Palich, L. E. (2008). Economic freedom and the motivation to engage in entrepreneurial action. Entrepreneurship Theory and Practice, 32(5), 875-895.

McMullen, J. S., \& Shepherd, D. A. (2006). Entrepreneurial action and the role of uncertainty in the theory of the entrepreneur. Academy of Management Review, 31(1), 132-152.

Meyers, C., \& Jones, T. B. (1993). Promoting active learning: Strategies for the college classroom. San Francisco, CA: Jossey-Bass Inc.

Miller, T. L., Grimes, M. G., McMullen, J. S., \& Vogus, T. J. (2012). Venturing for others with heart and head: How compassion encourages social entrepreneurship. Academy of Management Review, 37(4), 616-640.

Mitchell, J. R., \& Shepherd, D. A. (2010). To thine own self be true: Images of self, images of opportunity, and entrepreneurial action. Journal of Business Venturing, 25(1), 138-154.

Montes, G. M., Martin, E. P., Bayo, J. A., \& Garcia, J. O. (2011). The applicability of computer simulation using Monte Carlo techniques in windfarm profitability analysis. Renewable and Sustainable Energy Reviews, 15(9), 4746-4755.

Morris, M. H., Kuratko, D. F., \& Covin, J. G. (2010). Corporate entrepreneurship \& innovation. Andover: Cengage Learning. 
Morrison, E. W., Wheeler-Smith, S. L., \& Kamdar, D. (2011). Speaking up in groups: A cross-level study of group voice climate and voice. Journal of Applied Psychology, 96(1), 183-191.

Mueller, W. F. (1962). The origins of the basic inventions underlying Du Pont's major product and process innovations, 1920 to 1950. In R. R. Nelson (Ed.), The rate and direction of inventive activity: Economic and social factors (pp. 323-358). Princeton: Princeton University Press.

Naumann, S. E., \& Bennett, N. (2000). A case for procedural justice climate: Development and test of a multilevel model. Academy of Management Journal, $43(5), 881-889$.

Nonaka, I., \& Takeuchi, H. (1995). The knowledge-creating company: How Japanese companies create the dynamics of innovation. New York: Oxford University Press.

O’Connor, G. C. (1998). Market learning and radical innovation: A cross case comparison of eight radical innovation projects. Journal of product innovation management, 15(2), 151-166.

O'Connor, G. C., \& Veryzer, R. W. (2001). The nature of market visioning for technology-based radical innovation. Journal of Product Innovation Management, 18(4), 231-246.

Ocasio, W. (1997). Towards an attention-based view of the firm. Strategic Management Journal, 18(S1), 187-206.

Patel, P. C., \& Fiet, J. O. (2009). Systematic search and its relationship to firm founding. Entrepreneurship Theory and Practice, 33(2), 501-526.

Patzelt, H., \& Shepherd, D. A. (2008). The decision to persist with underperforming alliances: The role of trust and control. Journal of Management Studies, 45(7), 1217-1243.

Patzelt, H., \& Shepherd, D. A. (2010). Recognizing opportunities for sustainable development. Entrepreneurship Theory and Practice, 35(4), 631-652.

Peredo, A. M., \& Chrisman, J. J. (2006). Toward a theory of community-based enterprise. Academy of Management Review, 31(2), 309-328.

Peteraf, M. A., \& Bergen, M. E. (2003). Scanning dynamic competitive landscapes: A market-based and resource-based framework. Strategic Management Journal, 24(10), 1027-1041.

Pierce, J. L., Kostova, T., \& Dirks, K. T. (2001). Toward a theory of psychological ownership in organizations. Academy of Management Review, 26(2), 298-310.

Pinson, S. D., Louçã, J. A., \& Moraitis, P. (1997). A distributed decision support system for strategic planning. Decision Support Systems, 20(1), 35-51.

Rahmandad, H. (2008). Effect of delays on complexity of organizational learning. Management Science, 54(7), 1297-1312.

Reiss, S. (1991). Expectancy model of fear, anxiety, and panic. Clinical Psychology Review, 11(2), 141-153. 
Riedl, D. F., Kaufmann, L., Zimmermann, C., \& Perols, J. L. (2013). Reducing uncertainty in supplier selection decisions: Antecedents and outcomes of procedural rationality. Journal of Operations Management, 31(1), 24-36.

Rosenberg, N. (1982). Inside the black box: Technology and economics. Cambridge: Cambridge University Press.

Salomo, S., Talke, K., \& Strecker, N. (2008). Innovation field orientation and its effect on innovativeness and firm performance. Journal of Product Innovation Management, 25(6), 560-576.

Sandberg, J., \& Tsoukas, H. (2011). Grasping the logic of practice: Theorizing through practical rationality. Academy of Management Review, 36(2), 338-360.

Santos, F. M., \& Eisenhardt, K. M. (2009). Constructing markets and shaping boundaries: Entrepreneurial power in nascent fields. Academy of Management Journal, 52(4), 643-671.

Schmidt, J. B., Sarangee, K. R., \& Montoya, M. M. (2009). Exploring new product development project review practices. Journal of Product Innovation Management, 26(5), 520-535.

Schneider, B., Ehrhart, M. G., \& Macey, W. H. (2013). Organizational climate and culture. Annual Review of Psychology, 64, 361-388.

Schultz, C., Salomo, S., Brentani, U., \& Kleinschmidt, E. J. (2013). How formal control influences decision-making clarity and innovation performance. Journal of Product Innovation Management, 30(3), 430-447.

Seshadri, S., \& Subrahmanyam, M. (2005). Introduction to the Special Issue on "Risk Management in Operations". Production and Operations Management, 14(1), 1-4.

Sethi, R., \& Iqbal, Z. (2008). Stage-gate controls, learning failure, and adverse effect on novel new products. Journal of Marketing, 72(1), 118-134.

Shan, W., Walker, G., \& Kogut, B. (1994). Interfirm cooperation and startup innovation in the biotechnology industry. Strategic Management Journal, $15(5), 387-394$.

Shane, S. (2000). Prior knowledge and the discovery of entrepreneurial opportunities. Organization Science, 11(4), 448-469.

Shane, S., Locke, E. A., \& Collins, C. J. (2003). Entrepreneurial motivation. Human Resource Management Review, 13(2), 257-279.

Shepherd, D. A. (2015). Party on! A call for entrepreneurship research that is more interactive, activity based, cognitively hot, compassionate, and prosocial. Journal of Business Venturing, 30(4), 489-507.

Shepherd, D. A., \& DeTienne, D. R. (2005). Prior knowledge, potential financial reward, and opportunity identification. Entrepreneurship Theory and Practice, 29(1), 91-112.

Shepherd, D. A., McMullen, J. S., \& Jennings, P. D. (2007). The formation of opportunity beliefs: Overcoming ignorance and reducing doubt. Strategic Entrepreneurship Journal, 1(1-2), 75-95. 
Shepherd, D. A., McMullen, J. S., \& Ocasio, W. (2016). Is that an opportunity? An attention model of top managers' opportunity beliefs for strategic action. Strategic Management Journal. doi:10.1002/smj.2499.

Shepherd, D. A., \& Patzelt, H. (2011). The new field of sustainable entrepreneurship: Studying entrepreneurial action linking "what is to be sustained" with "what is to be developed". Entrepreneurship Theory and Practice, 35(1), 137-163.

Shepherd, D. A., \& Patzelt, H. (2013). Operational entrepreneurship: How operations management research can advance entrepreneurship. Production and Operations Management, 22(6), 1416-1422.

Shepherd, D. A., \& Sutcliffe, K. M. (2011). Inductive top-down theorizing: A source of new theories of organization. Academy of Management Review, 36(2), 361-380.

Shepherd, D. A., Wiklund, J., \& Haynie, J. M. (2009). Moving forward: Balancing the financial and emotional costs of business failure. Journal of Business Venturing, 24(2), 134-148.

Simangunsong, E., Hendry, L. C., \& Stevenson, M. (2016). Managing supply chain uncertainty with emerging ethical issues. International Journal of Operations and Production Management, 36(10), 1272-1307.

Smith, K. A., \& DeGregorio, D. D. (2002). Biosocialization, discovery, and entrepreneurial action. In M. Hitt, D. Ireland, M. Camp, \& D. Sexton (Eds.), Strategic entrepreneurship: Creating an integrated mindset. Oxford: Blackwell.

Sommer, S. C., \& Loch, C. H. (2004). Selectionism and learning in projects with complexity and unforeseeable uncertainty. Management Science, 50(10), 1334-1347.

Song, J. D., \& Kim, J. C. (2001). Is five too many? Simulation analysis of profitability and cost structure in the Korean mobile telephone industry. Telecommunications Policy, 25(1), 101-123.

Staw, B. M. (1981). The escalation of commitment to a course of action. Academy of Management Review, 6(4), 577-587.

Staw, B. M. (1997). The escalation of commitment: An update and appraisal. In Z. Shapira (Ed.), Organizational decision making (pp. 191-215). Cambridge: Cambridge University Press.

Staw, B. M., Barsade, S. G., \& Koput, K. W. (1997). Escalation at the credit window: A longitudinal study of bank executives' recognition and write-off of problem loans. Journal of Applied Psychology, 82(1), 130-142.

Sterman, J. D. (2000a). Business dynamics. New York: McGraw-Hill.

Sterman, J. D. (2000b). Learning in and about complex systems. Reflections, 1(3), 24-51.

Sun, L., Hong, L. J., \& Hu, Z. (2014). Balancing exploitation and exploration in discrete optimization via simulation through a Gaussian process-based search. Operations Research, 62(6), 1416-1438. 
Szulanski, G. (1996). Exploring internal stickiness: Impediments to the transfer of best practice within the firm. Strategic Management Journal, 17, 27-43.

Talke, K., Salomo, S., \& Rost, K. (2010). How top management team diversity affects innovativeness and performance via the strategic choice to focus on innovation fields. Research Policy, 39(7), 907-918.

Tatikonda, M. V., \& Montoya-Weiss, M. M. (2001). Integrating operations and marketing perspectives of product innovation: The influence of organizational process factors and capabilities on development performance. Management Science, 47(1), 151-172.

Tatikonda, M. V., \& Rosenthal, S. R. (2000). Successful execution of product development projects: Balancing firmness and flexibility in the innovation process. Journal of Operations Management, 18(4), 401-425.

Taylor, S. (2014). Anxiety sensitivity: Theory, research, and treatment of the fear of anxiety. New York: Routledge.

Teece, D. J. (1996). Firm organization, industrial structure, and technological innovation. Journal of Economic Behavior \& Organization, 31(2), 193-224.

Teece, D. J., Pisano, G., \& Shuen, A. (1997). Dynamic capabilities and strategic management. Strategic Management Journal, 18(7), 509-533.

Thornhill, S. (2006). Knowledge, innovation and firm performance in high-and low-technology regimes. Journal of Business Venturing, 21(5), 687-703.

Tilton, J. E. (1971). International diffusion of technology: The case of semiconductors. Washington, DC: Brookings Institution Press.

Tomlin, B. (2003). Capacity investments in supply chains: Sharing the gain rather than sharing the pain. Manufacturing \& Service Operations Management, 5(4), 317-333.

Tornikoski, E. T., \& Newbert, S. L. (2007). Exploring the determinants of organizational emergence: A legitimacy perspective. Journal of Business Venturing, 22(2), 311-335.

Tripsas, M., \& Gavetti, G. (2000). Capabilities, cognition, and inertia: Evidence from digital imaging. Strategic Management Journal, 21(10-11), 1147-1161.

Tsai, W. (2001). Knowledge transfer in intraorganizational networks: Effects of network position and absorptive capacity on business unit innovation and performance. Academy of Management Journal, 44(5), 996-1004.

Tsai, K. H., Chang, H. C., \& Peng, C. Y. (2016). Refining the linkage between perceived capability and entrepreneurial intention: Roles of perceived opportunity, fear of failure, and gender. International Entrepreneurship and Management Journal. doi:10.1007/s11365-016-0383-x.

Urban, G. L., \& Hauser, J. R. (1993). Designing and marketing of new products. Englewood Cliffs, NJ: Prentice Hall.

Van de Vrande, V. (2013). Balancing your technology-sourcing portfolio: How sourcing mode diversity enhances innovative performance. Strategic Management Journal, 34(5), 610-621. 
Van Wijk, R., Van den Bosch, F., \& Volberda, H. (2001). The impact of knowledge depth and breadth of absorbed knowledge on levels of exploration and exploitation. Paper presented at the annual meeting of the Academy of Management, Washington, DC.

Vermeulen, F., \& Barkema, H. (2001). Learning through acquisitions. Academy of Management Journal, 44(3), 457-476.

Veryzer, R. W. (1998). Discontinuous innovation and the new product development process. Journal of Product Innovation Management, 15(4), 304-321.

Vickery, S. K., Jayaram, J., Droge, C., \& Calantone, R. (2003). The effects of an integrative supply chain strategy on customer service and financial performance: An analysis of direct versus indirect relationships. Journal of Operations Management, 21(5), 523-539.

Vivares, J. A., Sarache Castro, W. A., \& Naranjo-Valencia, J. C. (2016). Impact of human resource management on performance in competitive priorities. International Journal of Operations \& Production Management, 36(2), $114-134$.

von Hippel, E. (1988). The sources of innovation. New York: Oxford University Press.

Walsh, J. P. (1995). Managerial and organizational cognition: Notes from a trip down memory lane. Organization Science, 6(3), 280-321.

Walsh, J. P., \& Ungson, G. R. (1991). Organizational memory. Academy of Management Review, 16, 57-91.

Wagner, S. H., Parker, C. P., \& Christiansen, N. D. (2003). Employees that think and act like owners: Effects of ownership beliefs and behaviors on organizational effectiveness. Personnel Psychology, 56(4), 847-871.

Weick, K. E. (1999). Theory construction as disciplined reflexivity: Tradeoffs in the 90s. Academy of Management Review, 24(4), 797-806.

Weinstein, N. D., \& Klein, W. M. (1995). Resistance of personal risk perceptions to debiasing interventions. Health Psychology, 14(2), 132-140.

Wood, M. S., McKelvie, A., \& Haynie, J. M. (2014). Making it personal: Opportunity individuation and the shaping of opportunity beliefs. Journal of Business Venturing, 29(2), 252-272.

Zahra, S. A., \& Chaples, S. S. (1993). Blind spots in competitive analysis. Academy of Management Executive, 7(2), 7-28.

Zahra, S. A., \& Covin, J. G. (1995). Contextual influences on the corporate entrepreneurship-performance relationship: A longitudinal analysis. Journal of Business Venturing, 10(1), 43-58.

Zahra, S. A., \& George, G. (2002). Absorptive capacity: A review, reconceptualization, and extension. Academy of Management Review, 27(2), 185-203.

Zimmerman, B. J., \& Pons, M. M. (1986). Development of a structured interview for assessing student use of self-regulated learning strategies. American Educational Research Journal, 23(4), 614-628. 
Zohar, A., \& Barzilai, S. (2013). A review of research on metacognition in science education: Current and future directions. Studies in Science Education, 49(2), 121-169.

Zohar, A., \& Dori, Y. J. (2003). Higher order thinking skills and low-achieving students: Are they mutually exclusive? The Journal Of The Learning Sciences, $12(2), 145-181$.

Open Access This chapter is distributed under the terms of the Creative Commons Attribution 4.0 International License (http://creativecommons.org/licenses/by/4.0/), which permits use, duplication, adaptation, distribution and reproduction in any medium or format, as long as you give appropriate credit to the original author(s) and the source, provide a link to the Creative Commons license and indicate if changes were made.

The images or other third party material in this chapter are included in the work's Creative Commons license, unless indicated otherwise in the credit line; if such material is not included in the work's Creative Commons license and the respective action is not permitted by statutory regulation, users will need to obtain permission from the license holder to duplicate, adapt or reproduce the material.

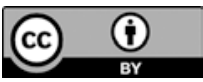

